\title{
KONTINUITAS HUKUM TAURAT DALAM SURAT GALATIA MENURUT PEMIKIRAN DOUGLAS J. MOO
}

\author{
Budiman Thia \\ GRII Kebon Jeruk
}

\begin{abstract}
The debate among the scholars on "Paul and the Law", Douglas J. Moo holds to the position of Reformed tradition. Moo in the commentary of Galatians claims that the Law although has no direct authority, yet it remains an indirect source for God's people in the New Testament. This paper will show how Moo articulate his thought in the commentary of Galatians, which in turn benefits Christians in understanding the continuity of the Law in one of Paul's epistles.
\end{abstract}

KEYWORDS: Continuity of Torah, Epistle of Galatians, Gospel and the Law, Authority of the Law, Paul and the Law.

ABSTRAK: Dalam perdebatan "Paulus dan hukum Taurat" di kalangan para ahli, Douglas J. Moo mempertahankan posisi tradisi Reformed. Moo di dalam tafsiran surat Galatia menyatakan bahwa sekalipun hukum Taurat tidak memiliki otoritas langsung, tetapi tetap menjadi sumber secara tidak langsung untuk umat Allah dalam Perjanjian Baru. Dalam tulisan ini akan dibuktikan bagaimana Moo dalam surat Galatia menunjukkan pemikiran ini, yang tentu memberi manfaat bagi orang Kristen dalam mengerti kontinuitas hukum Taurat dalam salah satu surat Paulus.

KATA-KATA KUNCI: Kontinuitas Taurat, Surat Galatia, Injil dan Taurat, otoritas Taurat, Paulus dan Taurat. 


\section{Pendahuluan}

Pemikiran Paulus tentang hukum Taurat sangatlah rumit. ${ }^{1}$ Karena disatu pihak, Paulus mengindikasikan hukum Taurat harus digenapi di dalam hidup orang Kristen (Roma 8:4; Galatia 5:14). Namun di pihak lain, Paulus mengatakan orang Kristen sudah mati dan dibebaskan dari hukum Taurat (Roma 7:4, 6; Galatia 2:19; 5:1). Dengan demikian, Paulus kelihatannya memiliki pemikiran ambivalen terhadap hukum Taurat. ${ }^{2}$ Oleh sebab pemikiran Paulus demikian, membawa banyak sarjana Paulus ke dalam perdebatan sengit pandangan Paulus mengenai kontinuitas hukum Taurat bagi kehidupan orang Kristen. ${ }^{3}$

Untuk meneliti kontinuitas hukum Taurat bagi kehidupan orang Kristen, maka Surat Roma dan Galatia adalah dua tulisan Paulus yang secara kasatmata berbicara secara eksplisit mengenai ketegangan hukum Taurat bagi kehidupan orang Kristen. Kedua surat ini menunjukkan kemiripan struktur pembahasan dan alur pemikiran dari Paulus. ${ }^{4}$ Untuk

1 Demikian kesimpulan dari beberapa ahli. Lih. Ben Witherington III, The Paul Quest: The Renewed Search for the Jew of Tarsus (Downers Grove: IVP, 1998), 66; Donald A. Hagner, "Paul as a Jewish Believer - According to His Letters", dalam Jewish Believers in Jesus: The Early Centuries, ed. Oskar Skarsaune dan Reidar Hvalvik (Peabody: Hendrickson, 2007), 104; D. A. Carson, "Mystery and Fulfillment: Toward a More Comprehensive Paradigm of Paul's Understanding of the Old and the New", dalam Justification and Variegated Nomism, vol. 2: The Paradoxes of Paul, ed. D. A. Carson, P. T. O'Brien, dan M. A. Seifrid (Grand Rapids: Baker Academic, 2004), 393; James D. G. Dunn, The New Perspective on Paul (Grand Rapids: Eerdmans, 2008), 441; Heikki Räisänen, Paul and the Law, ed ke-2 (Tübingen: Mohr, 1987), xii; Brian S. Rosner, Paul and the Law: Keeping the Commandments of God, NSBT, vol. 31 (Downers Grove: IVP, 2013), 19; Thomas R. Schreiner, The Law and Its Fulfillment: A Pauline Theology of Law (Grand Rapids: Baker, 1998), 13.

2 Di sisi negatif, hukum Taurat membawa kutuk (Gal. 3:13), membawa dosa dan kematian (1Kor. 15:56). Di sisi positif, hukum Taurat adalah kudus, benar, dan baik (Rm. 7:12), serta digenapi didalam hukum kasih (Rm. 13:8-10; Gal. 5:14). Paulus sendiri juga memelihara hukum Taurat seperti yang diusulkan oleh Yakobus di Yerusalem (Kis. 21:1526).

3 Beberapa karya akademis dengan judul Paulus dan hukum Taurat telah terbit. Lih. Hans Hubner, Law in Paul's Thought: A Contribution to the Development of Pauline Theology, Studies of the New Testament and Its World (London: T. \& T. Clark, 2004); Heikki Raiisainen, Paul and the Law (Philadelphia: Fortress, 1983); Brice L. Martin, Christ and the Law in Paul (Leiden: E.J. Brill, 1989); Brian S. Rosner, Paul and the Law: Keeping the Commandments of God, NSBT, vol. 31 (Downers Grove: IVP, 2013); James D. G. Dunn, Jesus, Paul, and the Law: Studies in Mark and Galatians (Louisville, Ky:: Westminster John Knox Press, 1990).

4 Udo Schnelle, Apostle Paul: His Life and Theology, trans. M Eugene Boring (Grand Rapids: Baker Academic, 2012), 270. 
membatasi lingkup pembahasan, maka artikel ini akan menggunakan surat Galatia sebagai test case untuk pembahasan kontinuitas hukum Taurat.

Adapun tokoh yang dibahas adalah Douglas J. Moo, seorang sarjana Paulus yang sangat terkenal dalam lingkaran tradisi Reformed. ${ }^{5}$ Berkenaan dengan tulisan Paulus, Moo sudah menghasilkan tafsiran mengenai surat Roma dan surat Galatia. ${ }^{6}$ Moo sendiri mengklaim mengikuti tradisi Calvin dan tradisi Reformed. ${ }^{7}$

Untuk mendapatkan keutuhan pemikiran Moo mengenai kontinuitas hukum Taurat dalam surat Galatia, artikel ini akan membahas secara sinkronis surat Galatia dalam perikop-perikop yang berkenaan dengan hukum Taurat. Perikop-perikop yang akan dibahas, antara lain: 1:6-10, 2:11-14, 2:15-16, 3:10-14, 3:19-22, 5:1-6, 5:13-15, 5:16-26, 6:1-10. Sebelum masuk di dalam pembahasan perikop, akan dibahas latar belakang surat Galatia untuk memahami konteks surat tersebut menurut Moo.

\section{Latar Belakang Surat Galatia menurut Moo}

Moo mengakui "rasul Paulus" (Galatia 1:1) sebagai penulis surat Galatia tidak banyak dipersoalkan dari pemulaan gereja. Walaupun

5 Gordon D. Fee selaku editor New International Commentary on the New Testament mengakui Moo sebagai "a first-rate exegete" dan pantas untuk mengganti edisi tafsiran surat Roma sebelumnya yang ditulis oleh John Murray. Lih. Douglas J. Moo, The Epistle to the Romans, The New International Commentary on the New Testament (Grand Rapids: Eerdmans, 1996), vii.

6 Tafsiran surat Roma: Douglas J. Moo, The Epistle to the Romans, The New International Commentary on the New Testament (Grand Rapids: Eerdmans, 1996); idem., Romans 1-8, Wycliffe Exegetical Commentary (Chicago: Moody, 1991); idem., Romans, The NIV Application Commentary (Grand Rapids: Zondervan, 2000); idem., Encountering the Book of Romans: A Theological Survey, Encountering Biblical Studies (Grand Rapids: Baker Academic, 2002).

Tafsiran surat Galatia: Douglas J. Moo, Galatians, Baker Exegetical Commentary on the New Testament (Grand Rapids: Baker Academic, 2013).

7 "Following the lead of Calvin and many others in the Reformed tradition, we think it does much better justice to Paul ...", Moo Galatians, 56, Lih. juga 232. Di tempat lain, Moo secara eksplisit memposisikan diri mewakili "A Modified Lutheran View" dalam buku Greg L. Bahnsen, Five Views on Law and Gospel, Counterpoints (Grand Rapids: Zondervan, 1996), $319-76$. 
demikian, mungkin Paulus menggunakan amanuensis. Namun nuansa pribadi yang kental menunjukkan keterlibatan mendikte secara langsung. ${ }^{8}$

Setelah membahas panjang-lebar mengenai penerima surat, Moo memutuskan surat Galatia ditulis oleh Paulus kepada jemaat yang ada di Galatia Selatan. ${ }^{9}$ Hal tersebut tidak secara langsung membuat surat Galatia ditulis lebih awal. ${ }^{10}$ Namun, apabila ditelusuri dari catatan Kisah Para Rasul, Moo berpendapat peristiwa Galatia 2:1-10 merupakan peristiwa yang dicatat oleh Lukas dalam Kisah Para Rasul 11:27-30 (peristiwa bantuan kelaparan) dan bukan Kisah Para Rasul 15:1-29 (konsili di Yerusalem). Alasannya: (1) Galatia 2:2 menyinggung "percakapan tertutup" yang berbeda dengan Kisah Para Rasul 15:1-29 yang merupakan pertemuan terbuka; (2) Dorongan bagi Paulus ke Yerusalem (jikalau "pewahyuan" dari Galatia 2:1 dapat dimengerti sebagai nubuatan Kisah Para Rasul 11:27); (3) Keduanya mencatat dari Antiokhia ke Yerusalem; (4) Kehadiran Barnabas; (5) Berkaitan dengan bantuan kemanusiaan. ${ }^{11}$

Selain itu, Moo memperteguh pandangannya berdasarkan dua alasan yang implisit: (1) Dalam surat Galatia, Paulus hanya menyinggung dua kali kunjungan ke Yerusalem (Galatia 1:18; 2:1-10), sedangkan di Kisah Para Rasul, terdapat tiga kali (Kisah Para Rasul 9:26-29; 11:27-30; 15:1-29). Berarti kunjungan terakhir tersebut belum terjadi sebelum penulisan surat Galatia; (2) Paulus juga tidak menyinggung mengenai isi keputusan dari konsili di Yerusalem dalam surat Galatia. Setidaknya Paulus akan menyinggung keputusan berkaitan dengan sunat dalam

\footnotetext{
8 Moo, Galatians, 1.

9 Ibid., 2-8.

10 Ibid., 8. Moo membuat perbandingan teori "provinsi Galatia" (Galatia Selatan) dan teori "etnis Galatia" (Galatia Utara) yang dikaitkan dengan penanggalan. Penanggalan Galatia Selatan membuka peluang penanggalan relatif lebih awal sekitar tahun 48-57, sedangkan penanggalan Galatia Utara sekitar tahun 50-57 (Moo, Galatians, 9).

Mengenai pembahasan penerima surat (Galatia Utara/Selatan) dengan penanggalan (awal/ akhir) dapat merujuk kepada Fisk, "Paul: Life and Letters", 283-325; Guthrie, New Testament Introduction, 465-482, khususnya bagian "Destination of the Epistle" dan "Date".

11 Moo, Galatians, 13-14.
} 
surat Galatia. ${ }^{12}$

Dengan demikian, Moo berpendapat surat Galatia ditulis sebelum konsili di Yerusalem (Kisah Para Rasul 15:1-29). ${ }^{13}$ Sehingga sangat mungkin setelah kehadiran si pengacau (Galatia 1:7; Kisah Para Rasul 15:1), Paulus segera menuliskan surat Galatia. Setelah itu, disusul dengan kunjungannya ke Yerusalem untuk membicarakan hal tersebut secara terbuka (Kisah Para Rasul 15:1-29). ${ }^{14}$ Dengan menempatkan surat Galatia sebelum konsili di Yerusalem, berarti permasalahan di Antiokhia dibawa kepada konsili secara terbuka di Yerusalem untuk diselesaikan. Moo kemudian menyimpulkan penanggalan surat Galatia adalah tahun 48, dan merupakan surat paling awal dari Paulus. ${ }^{15}$

Dengan penanggalan Galatia sebelum konsili di Yerusalem, Moo sejalan dengan Calvin yang menghindari asumsi Petrus sebagai seorang rasul yang tidak konsisten. ${ }^{16}$

Mengenai konteks pergolakan jemaat di Galatia, Moo berpendapat bahwa Paulus menulis surat Galatia untuk menentang sekelompok orang Kristen (si pengacau, Galatia 1:7) yang mengharuskan jemaat Galatia untuk menjalankan sunat dan taat kepada hukum Musa sebagai sarana untuk mengenapi pengalaman Kekristenan mereka. ${ }^{17}$

Menurut Moo, si pengacau ini tentu merujuk kepada kisah Abraham sebagai dukungan untuk mempengaruhi jemaat Galatia. Mereka mengatakan bahwa Abraham percaya terlebih dahulu (Kejadian 15:6), setelah itu Abraham menjalankan sunat, demikian juga keturunannya laki-laki. Setelah sunat, Allah juga memberikan hukum Musa kepada keturunan Abraham, supaya mereka taati sehingga mereka

\footnotetext{
12 Ibid., 15-16.

13 Ibid., 16. Konsili di Yerusalem sekitar tahun 48 hingga 49. Lih. Dunn, The Cambridge Companion to St. Paul, xx; Carson \& Moo, An Introduction to the New Testament, 369, 464; Longenecker, Galatians, lxxiii.

14 Ibid., 16-17.

15 Ibid., 18.

16 John Calvin, Commentaries on the Epistles of Paul to the Galatians and Ephesians, terj. William Pringle (Bellingham: Logos Bible Software, 2010), 47.

17 Moo, Galatians, 19, 22.
} 
pantas disebut keturunan Abraham. ${ }^{18}$

Untuk menghadapi si pengacau, menurut Moo, Paulus menekankan kontinuitas sekaligus diskontinuitas dari Perjanjian Lama. Kunci untuk menjawab tantangan mereka ini adalah Paulus perlu menekankan signifikansi peristiwa penyaliban dan kebangkitan Kristus. Peristiwa ini telah menginaugurasi "ciptaan baru" (Galatia 6:15), dan disinilah letaknya status baru, dan sentralitas iman dan Roh, yang menandai "Israel milik Allah" (Galatia 6:16), umat sejati dari Allah dan keturunan dari Abraham. Dengan mengaitkan identitas orang percaya dengan Abraham, berarti hukum Taurat digenapi (bukan diganti, ataupun dibatalkan, Galatia 5:14). Hal ini menurut Paulus karena adanya kontinuitas di dalam sejarah keselamatan dari Allah. ${ }^{19}$

Hal inilah yang membedakan Paulus dan si pengacau tersebut. Karena Paulus mengintepretasinya berdasarkan peristiwa Kristus (Christ event), sedangkan si pengacau tidak, menurut Moo. Sehingga Paulus melihat hukum Taurat hanya bersifat sementara dan subordinat, serta dimaksudkan untuk mencapai sesuatu yang berbeda dari perjanjian Allah dengan Abraham (Galatia 3:15-25). ${ }^{20}$

Untuk menyelesaikan pergolakan ini, menurut Moo, Paulus membuat polarisasi antara "melakukan hukum Taurat" dan "iman dalam Kristus". Tentu hal ini merefleksikan sesuatu yang lebih fundamental, yaitu: perbandingan antara iman dan perbuatan manusia. ${ }^{21}$

Namun harus diakui, semenjak "revolusi Sanders" 22, menurut Moo, soteriologi Yudaisme dimengerti sebagai anugerah perjanjian Allah, sedangkan ketaatan kepada hukum Taurat bertujuan untuk mempertahankan status di dalam perjanjian Allah tersebut (covenantal nomism). Sehingga sulit untuk melakukan kontras antara Paulus dan

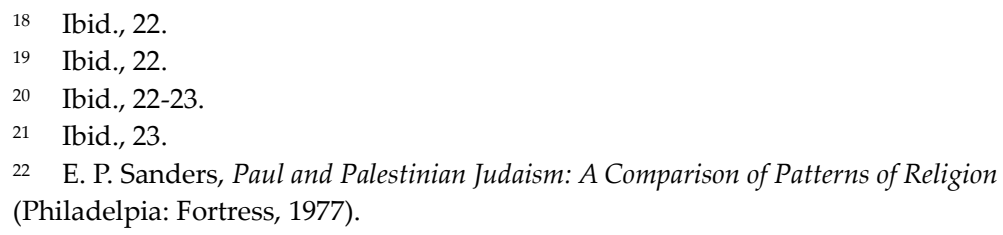


musuhnya, orang Kristen Yahudi, seperti sedia kala. Sebab konflik di dalam Galatia bukan ditafsirkan secara teologis maupun filosofis, melainkan secara historis. ${ }^{23}$ Dengan demikian, Moo ingin menegaskan bahwa Paulus bukan hanya menyelesaikan permasalahan covenantal nomism, melainkan terlebih lagi Paulus sedang mempermasalahkan tentang andil manusia untuk memperoleh pembenaran Allah.

Moo berpendapat, bahwa Paulus terlebih dahulu memperkenalkan

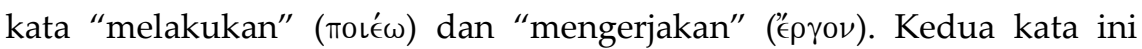
dapat diartikan "melakukan" dalam arti umum. Dan Paulus membuktikan manusia tidak sanggup untuk melakukan hukum Taurat secara sempurna karena dosa. ${ }^{24}$ Setelah itu baru Paulus

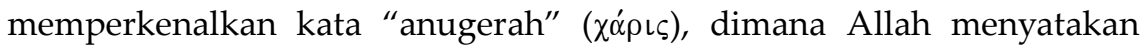
keselamatan di dalam Kristus, dan hanya dapat diresponi dengan iman. ${ }^{25}$

Setelah dibenarkan "melalui iman", manusia sudah tidak berada "di bawah hukum Taurat." Namun ini bukan berarti hukum Taurat sudah tidak berarti, menurut Moo. Sekalipun hukum Taurat tidak memiliki otoritas langsung, tetapi tetap menjadi sumber secara tidak langsung-melalui otoritas pengajaran Perjanjian Baru-untuk kehidupan moral orang percaya. ${ }^{26}$

\section{Galatia 1:6-10}

Paulus memulainya dengan menunjukkan keheranannya kepada jemaat Galatia yang "begitu lekas" ( $\left.\tau \alpha \chi \chi^{\prime} \omega \varsigma\right)$ berbalik. Seberapa "lekas" yang dimaksud Paulus? Menurut Moo, kata "lekas" ini dapat ditafsirkan: (1) lekas setelah kehadiran guru-guru palsu; (2) lekas setelah pertobatan mereka; (3) keputusan yang tergesa-gesa. Sehingga Moo, memutuskan bahwa "lekas" yang dimaksud adalah betapa singkatnya bentang waktu antara jemaat Galatia menerima Injil sejati yang diberitakan Paulus

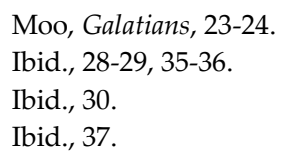


dengan ketertarikan mereka kepada guru-guru palsu. ${ }^{27}$

Kata inipun dapat mengalusikan peristiwa di dalam Perjanjian Lama, dimana orang Israel "begitu lekas" setelah mendengar firman Tuhan di Sinai dan berbalik beribadah kepada anak lembu emas (Keluaran 32:8). ${ }^{28}$ Namun menurut Moo, apabila Paulus bermaksud untuk mengalusikan kepada insiden tersebut, maka Paulus akan menggunakan kata "menyimpang" ( $\pi \alpha \rho \alpha \beta \alpha i \nu \omega$, Keluaran 32:8) dan bukan "berbalik" ( $\mu \in \tau \alpha \tau i \theta \eta \mu \iota$, Galatia 1:6). Sehingga Moo menyimpulkan bahwa kata metati,qhmi ini digunakan untuk menyatakan perubahan keyakinan filsafat ataupun politik, sehingga Paulus ingin menyatakan bahwa jemaat Galatia begitu cepat berubah keyakinan iman mereka. Selain itu, kata ini dalam bentuk present tense, mengindikasikan penyesatan dari si pengacau masih dalam tahap pertimbangan jemaat Galatia. ${ }^{29}$

Paulus selanjutnya memperkenalkan kata "injil". Kata ini berakar pada Perjanjian Lama, khususnya kitab Yesaya, dimana menubuatkan bahwa Allah akan menyampaikan "kabar baik" kepada umat-Nya. Salah satunya adalah mendeklarasikan bahwa "Allah memerintah" (Yesaya 52:7). Namun menurut Moo, penggunakan kata ini disini bukan berfokus kepada pemerintahan Allah maupun Kristus. Penggunaan disini dimaksudkan Paulus untuk menunjukkan berkat yang dibawa oleh Kristus sebagai Tuhan bagi umat-Nya. ${ }^{30}$

Dengan demikian "kabar baik" yang dimaksud Paulus adalah berita bahwa Allah melalui Kristus membuka jalan bagi orang berdosa untuk diterima oleh Allah. Hal ini merupakan anugerah Allah, baik masuk ke dalam maupun menghidupinya melalui iman semata. ${ }^{31}$ Sejalan dengan Calvin, Moo menekankan pentingnya anugerah dalam Injil. ${ }^{32}$

\footnotetext{
27 Ibid., 76.

28 Ibid., 76.

29 Ibid., 77.

$30 \quad$ Ibid., 78.

31 Ibid., 78.

32 Calvin sangat menekankan pentingnya anugerah di dalam Injil, seperti terlihat dalam pembahasan Gal. 1:6: "When he says that they were called by Christ through grace, this tends to heighten the criminality of their ingratitude. To revolt from the Son of God under
} 
Dengan demikian, Injil yang memikat jemaat Galatia adalah Injil menurut versi "si pengacau" (oi $\tau \alpha \rho \alpha ́ \sigma \sigma o \nu \tau \epsilon \varsigma)$. Si pengacau adalah

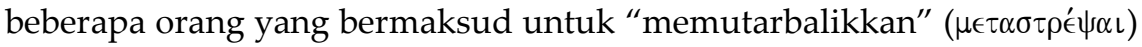
Injil Kristus. Walaupun demikian, kata "maksud" dalam bentuk present tense, menunjukkan upaya yang dilakukan oleh guru-guru palsu tersebut masih dalam proses dan belum sepenuhnya berhasil mempengaruhi jemaat Galatia sepenuhnya. ${ }^{33}$

Menurut Moo, Paulus selanjutnya menggunakan bahasa yang keras untuk menandai betapa seriusnya permasalahan yang ada. Sebab penyimpangan ini dapat menyebabkan guru-guru palsu ini secara harafiah masuk ke neraka ${ }^{34}$, termasuk jemaat Galatia yang mengikutinya. Kata $\alpha \nu \alpha ́ \theta \epsilon \mu \alpha$ secara literal berarti "di bawah kutuk", namun kata ini merefleksikan kata Ibrani הָרֵ yang berarti "sesuatu yang dikhususkan" dan umumnya "dikhususkan untuk dibinasakan". Sehingga kata ini berarti mengalami penderitaan dibawah murka Allah. ${ }^{35}$

Paulus juga mengikutsertakan "malaikat dari sorga" dalam argumentasinya. Menurut Moo, Paulus bisa saja mengaitkan peristiwa hukum Taurat diberikan melalui malaikat (Galatia 3:19). Namun, tidak terdapat bukti bahwa guru-guru palsu tersebut merujuk kepada pewahyuan dari malaikat. Oleh sebab itu, lebih tepat rujukan Paulus tersebut merupakan gaya bahasa hiperbolis. Dengan demikian,

any circumstances, is unworthy and disgraceful; but to revolt from him, after being invited to partake salvation by grace, is more eminently base. His goodness to us renders our ingratitude to him more dreadfully heinous." Lih. Calvin, Galatians \& Ephesians, 30.

Luther disisi lain menekankan pentingnya "pembenaran hanya melalui iman dan tanpa perbuatan" manusia: "The truth of the Gospel is this, that our righteousness comes by faith alone, without the works of the Law. The falsification or corruption of the Gospel is this, that we are justified by faith but not without the works of the Law. The false apostles preached the Gospel, but they did so with this condition attached to it." Lih. Martin Luther, Luther's Works, Vol. 26: Lectures on Galatians, 1535, Chapters 1-4, ed. Jaroslav Jan Pelikan, Hilton C. Osward dan Helmut T. Lehmann (Saint Louis: Concordia Publishing House, 1963), 26: 88 .

33 Moo, Galatians, 79-80.

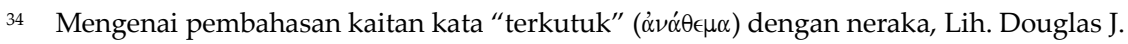
Moo, "What Does Paul Teach about Hell?" dalam Hell Under Fire, ed. Chris Morgan dan Rober Peterson (Grand Rapids: Zondervan, 2004), 91-109.

35 Moo, Galatians, 80. 
menunjukkan baik dirinya maupun utusan yang spektakuler sekalipun memberitakan injil yang salah, akan dikutuk oleh Allah. ${ }^{36}$

Tentu kata "terkutuklah" ( $\alpha \nu \alpha ́ \theta \epsilon \mu \alpha)$ tidak digunakan oleh Paulus secara gegabah. Dengan mempertimbangkan keseriusan permasalahan jemaat Galatia, Paulus mengulanginya lagi dalam ayat 9. Selain itu, Paulus juga mengingatkan bahwa hal tersebut "telah kami katakan dahulu." Menurut Moo, sangat mungkin Paulus pernah menasihatkan hal ini ketika melayani di Galatia. ${ }^{37}$

Paulus menambahkan, menurut Moo, bahwa Injil yang "telah kamu terima", sebagai pengalaman sejati jemaat Galatia akan anugerah Allah (Galatia 1:6). Sehingga pengalaman tersebut juga dapat menjadi bahan pertimbangan mereka terhadap ajaran yang salah dari si pengacau. ${ }^{38}$

Paulus menutup perikop ini dengan 2 pertanyaan. Paulus memulai dengan pertanyaan: "Apakah aku mencoba membujuk manusia atau Allah?" Hal ini menjadi jelas menurut Moo apabila dikaitkan dengan pertanyaan kedua: "Adakah kucoba berkenan kepada manusia?" Maka jelas jawabannya "tidak" dari Paulus. Sehingga bukan mencoba membujuk manusia, melainkan Allah. ${ }^{39}$

Lantas, bagaimana Paulus dapat "membujuk Allah"? Moo berpendapat, Paulus menunjukkan bahwa dirinya bukan mencari perkenanan manusia, melainkan perkenanan Allah. ${ }^{40}$ Di sini, Moo tidak membedakan kedua kata ini "membujuk" ( $\pi \epsilon i \theta \omega)$ dan "berkenan" $(\dot{\alpha} \rho \epsilon \in \sigma \kappa \omega)$ secara jelas.

Hal ini dilakukan oleh Paulus untuk mengelak semua tuduhan dari si pengacau bahwa Paulus sedang mencoba "memperkenan manusia". Disini, Paulus menegaskan bahwa jikalau dirinya "mencoba

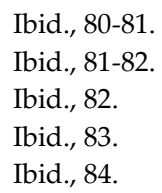


berkenan kepada manusia", maka dirinya bukanlah "hamba Kristus". ${ }^{41}$

Mungkin saja tuduhan dari para lawan Paulus benar, karena Paulus sendiri pernah menekankan pentingnya sunat sebelum pertobatannya (Galatia 5:11). Namun lebih tepat, menurut Moo, bahwa para lawan menuduh Paulus berlaku munafik. Alasannya: Paulus menyunat orang yang tepat baginya (mis: Timotius, Kisah Para Rasul 16:1-3) sedangkan tidak menyunat Titus pada kesempatan lain (Galatia 2:3). Dengan demikian, maka para lawannya menuduhnya mencoba "memperkenan manusia". ${ }^{42}$

Dalam perikop ini, Paulus mulai menunjukkan jarak pemisah yang jelas antara Injil sejati dengan Injil yang disusup dengan hukum Taurat menurut tradisi Yahudi.

\section{Galatia 2:11-14}

Ketika mengadakan konsultasi di Yerusalem (Galatia 2:1-10; Kisah Para Rasul 11:27-30)43, Paulus sepertinya mendapat persetujuan dari para rasul di Yerusalem untuk versi Injil bebas-hukum Taurat (law-free gospel). Sehingga kebenaran Injil dapat dipertahankan untuk jemaat non-Yahudi. Namun hal tersebut sepertinya tidak demikian ketika Paulus ada di Antiokhia selang beberapa waktu kemudian. Sebab Paulus harus menentang salah seorang rasul (Petrus), untuk mempertahankan Injil tersebut. ${ }^{44}$

Hal ini disebabkan karena terjadi kontroversi dimana Petrus dan orang Yahudi lainnya menarik diri untuk tidak makan sehidangan dengan orang non-Yahudi. Menurut Moo, walaupun terdapat perbedaan pandangan diantara para ahli mengenai seberapa jauh orang Yahudi boleh berhubungan dengan orang non-Yahudi. Namun yang pasti,

\footnotetext{
$41 \quad$ Ibid., 84.

$42 \quad$ Ibid., 84-85.

43 Harus dibedakan antara konsultasi di Yerusalem (Gal. 2:1-10; Kis. 11:27-30) sekitar tahun 45-47, dengan konsili di Yerusalem (Kis. 15:1-29) sekitar tahun 48-49 (Galatians, 8-18, 141, 145).

44 Moo, Galatians, 141.
} 
insiden di Antiokhia menunjukkan bahwa orang Yahudi yang taat dan saleh sedapat mungkin menghindar dari orang non-Yahudi. ${ }^{45}$

Mengikuti Bauckham, Moo berpendapat bahwa Petrus, dan utusan dari Yakobus takut bahwa diri mereka akan terkontaminasi oleh kecemaran orang non-Yahudi. ${ }^{46}$ Hal ini bukan disebabkan karena makanan yang disajikan, ataupun jenis makanannya. Melainkan relasi intim dengan orang non-Yahudi menyebabkan diri mereka tercemar. ${ }^{47}$

Petrus setelah tiba di Antiokhia dan tinggal beberapa lama disana, mulai mengikuti cara hidup jemaat Antiokhia, yaitu orang Yahudi dan non-Yahudi berbaur bersama, termasuk makan bersama (Kisah Para Rasul 11:19-26). ${ }^{48}$

Dengan kehadiran utusan dari Yakobus, Petrus mengalami tekanan dari mereka dan mengambil langkah taktis untuk mengundurkan diri dari orang non-Yahudi untuk mengakomodasi orang Kristen Yahudi yang ketat. Hal ini dilihat secara berbeda oleh Paulus. Bagi Paulus tindakan sedemikian berarti Petrus sudah menganggap orang non-Yahudi tidak benar-benar disucikan dosanya oleh Kristus, mereka dianggap harus menjalankan tradisi Yahudi untuk menyucikan dosa mereka. Hal inilah yang ditentang Paulus, sebab sudah menyimpang dari kebenaran Injil. ${ }^{49}$ Ini bukan sekadar masalah keputusan yang telah dibuat dan dilanggar, namun lebih dari itu, yakni kemurnian Injil telah terkontaminasi, seperti dikatakan Calvin. ${ }^{50}$

Lantas, bagaimana kaitan insiden di Antiokhia dengan keputusan yang sudah diambil dalam konsultasi di Yerusalem? Menurut Moo, hasil keputusan yang diambil dalam konsultasi tersebut secara inheren sangat

\footnotetext{
45 Ibid., 142.

46 Ibid., 142; Richard Bauckham, "James, Peter, and the Gentiles", dalam The Missions of James, Peter, and Paul: Tensions in Early Christianity, ed. Bruce Chilton dan Craig A. Evans (Leiden: Brill, 2005), 93-142.

47 Moo, Galatians, 143.

48 Ibid., 143.

49 Ibid., 143.

50 "This was no affair of men, but involved the purity of the gospel, which was in danger of being contaminated by Jewish leaven." Lih. Calvin, Galatians E Ephesians, 64.
} 
ambigu dan tidak komprehensif. Sebab dalam konsultasi tersebut, para rasul di Yerusalem mengakui keabsahan Injil bebas-hukum Taurat (lawfree gospel) yang diberitakan oleh Paulus kepada jemaat non-Yahudi. Namun dalam penerapannya, konsultasi di Yerusalem hanya dialamatkan kepada apa yang diharuskan dari petobat non-Yahudi dan tidak berkenaan dengan bagaimana orang Kristen Yahudi harus berelasi dengan petobat non-Yahudi, sehingga insiden di Antiokhia ini bisa terjadi. ${ }^{51}$

Hasil konsultasi tersebut diresepsi secara berbeda oleh Paulus dan Petrus. Bagi Petrus, konsultasi di Yerusalem tidak mencakup perihal yang terjadi di Antiokhia secara eksplisit. Sedangkan bagi Paulus, konsultasi di Yerusalem ini adalah prinsipil, di mana Paulus sengaja mengutip kasus Titus yang "tidak dipaksa untuk menyunatkan dirinya" turut ikut dalam konsultasi tersebut (Galatia 2:1-4). Hal ini menyatakan bahwa Titus yang adalah orang non-Yahudi juga mendapatkan keanggotaan penuh dan setara dengan orang Kristen Yahudi. Dengan demikian, bagi Paulus konsultasi tersebut secara implisit sudah menunjukkan penerimaan antara orang Yahudi dan non-Yahudi, termasuk juga makan bersama. ${ }^{52}$

Paulus sengaja mencatat insiden di Antiokhia ini kepada jemaat di Galatia, karena sangat mungkin Petrus (dan mungkin Barnabas) tidak berubah pendirian, setelah insiden tersebut. Namun Moo menegaskan ada dua alasan mengapa insiden ini dicatat dalam surat Galatia: (1) Lokasi Antiokhia tidak berjauhan dari Galatia, sehingga jemaat Galatia tentu sudah mendengar perihal mengenai insiden tersebut. Mungkin juga si pengacau menceritakan insiden Antiokhia versi mereka untuk mempengaruhi jemaat di Galatia. Oleh sebab itu, Paulus perlu meluruskan permasalahan yang ada; (2) Insiden di Antiokhia menjadi jalan masuk kepada argumentasi di Galatia. Berhubung isu utama yang dihadapi jemaat Galatia juga berkenaan dengan jemaat non-Yahudi yang

\footnotetext{
51 Moo, Galatians, 143.

52 Ibid., 143-44; Bauckham, "James, Peter, and the Gentiles", 122.
} 
diharuskan untuk mengikuti ritual Yahudi supaya mendapatkan keanggotaan penuh sebagai umat Allah. ${ }^{53}$

Menurut Moo, Paulus memulai ayat 11 tanpa pendahuluan mengenai masalah yang dipersengketakan, maupun bagaimana insiden ini bermula. Paulus segera menyatakan konfrontasinya secara terang-

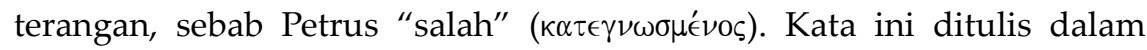
bentuk perfect tense, untuk menunjukkan penekanan stative. Dengan demikian, Petrus dalam status terhukum. Alasannya, karena Paulus menganggap Petrus dalam status terhukum oleh Allah. ${ }^{54}$

Moo mengakui di balik keenganan orang Yahudi untuk berelasi dengan orang non-Yahudi karena situasi sosial-politik pada masa tersebut. Khususnya karena penganiayaan di zaman Maccabeus dan juga orang Yahudi diperasingan (diaspora). Sehingga orang Yahudi membangun pembatas antara diri mereka dengan orang non-Yahudi untuk mempertahankan identitas keagamaan mereka. ${ }^{55}$

Paulus melihat bahwa Petrus, Barnabas dan jemaat Kristen Yahudi bukan saja tidak menghidupi apa yang mereka yakini (munafik, Galatia 2:13). Namun terlebih lagi, sudah tidak seturut dengan "kebenaran Injil" ( ini adalah: kebenaran ditegakkan hanya dengan Injil, dan Injil adalah benar-benar Injil hanya jika itu sesuai dengan kebenaran. Sehingga menurut Moo, Injil memiliki kuasa inheren, dimana melalui anugerah Allah dapat membenarkan dan membela setiap manusia pada penghakiman terakhir. Selain itu, Injil juga memiliki kuasa untuk membawa orang non-Yahudi ke dalam relasi dengan Allah dan memelihara mereka dalam relasi tersebut hingga hari penghakiman. ${ }^{56}$

\footnotetext{
53 Moo, Galatians, 144.

54 Ibid., 145.

55 Ibid., 148.

56 Ibid., 130. Lih. juga Douglas J. Moo, “Romans 2: Saved Apart from the Gospel?” dalam Through No Fault of their Own: The Fate of Those Who have Never Heard, ed. W. Crockett dan J. Sigountos (Grand Rapids: Baker, 1991), 137-45.
} 
Sehingga baik konsultasi di Yerusalem (Galatia 2:1-10), insiden di Antiokhia (Galatia 2:11-14), maupun krisis di Galatia menunjukkan bahwa Paulus menitikberatkan unsur anugerah dari Injil. Sehingga segala bentuk obligasi diluar iman kepada Kristus sudah merupakan "suatu injil lain, yang sebenarnya bukan Injil." (Galatia 1:6-7). ${ }^{57}$

Menurut Moo, Paulus selanjutnya membandingkan kedua kata

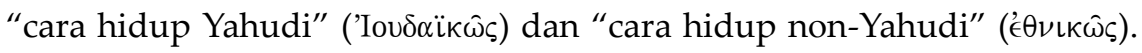
Hal ini dilakukan oleh Paulus untuk mengecam gaya hidup Petrus yang sudah ditinggalkannya (cara hidup Yahudi) dan mengadopsi cara hidup non-Yahudi. Dengan berbalik kembali kepada cara hidup Yahudi, berarti Petrus sudah memaksa jemaat non-Yahudi untuk mengadopsi cara hidup Yahudi. Namun sejauh apa Petrus maupun orang Kristen Yahudi sudah meninggalkan cara hidup Yahudi, Moo tidak dapat memastikan. ${ }^{58}$

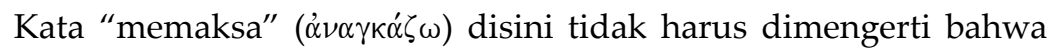
Petrus menggunakan otoritas kerasulannya untuk memaksa jemaat nonYahudi untuk hidup menurut cara hidup Yahudi. Menurut Moo, sikap dari Petrus dan orang Kristen Yahudi yang berlaku "munafik" tersebut sudah memberi tekanan kepada jemaat non-Yahudi. ${ }^{59}$

Oleh sebab itu, menurut Moo, implikasinya adalah jemaat Galatia harus mengikuti persyaratan jemaat Yahudi, mereka harus tunduk kepada hukum Taurat supaya dapat membangun kembali relasi dengan jemaat Yahudi. Bagi Paulus, persyaratan sedemikian berarti sudah meninggalkan anugerah Allah, yang merupakan unsur dasar dari Injil. ${ }^{60}$

\section{Galatia 2:15-16}

Melanjutkan pembahasan insiden di Antiokhia, Paulus mengingatkan jemaat Galatia dengan mengontraskan antara "orang Yahudi karena kelahiran", yaitu mereka yang secara status diturunkan oleh leluhur, dibandingkan dengan "orang berdosa dari non-Yahudi".

\footnotetext{
Moo, Galatians, 150.

Ibid., 150.

Ibid., 151.

60 Ibid., 151.
} 
Menurut Moo, Paulus menggunakan bahasa Yahudi, dimana menilai non-Yahudi sebagai mereka yang "tidak termasuk kewargaan Israel dan tidak mendapat bagian dalam ketentuan-ketentuan yang dijanjikan, tanpa pengharapan dan tanpa Allah di dalam dunia." (Efesus 2:12). Paulus sengaja menggunakan bahasa sedemikian, untuk menunjukkan kelemahan konsep tersebut. Dengan demikian, menjadi frasa pendahuluan untuk menunjukkan bahwa baik orang Yahudi maupun orang non-Yahudi adalah orang "berdosa" dan karena itu sama-sama membutuhkan pembenaran dalam Kristus. ${ }^{61}$

Menurut Moo, Paulus secara eksplisit menggunakan kata "kami" ( (dan juga jemaat Kristen Yahudi) sudah "mengetahui" bahwa tidak ada seorangpun yang dibenarkan karena "melakukan hukum Taurat". Sehingga sudah pasti baik Paulus, Petrus, si pengacau, dan termasuk juga jemaat Galatia tidak meragukan akan pernyataan "dibenarkan karena iman dalam Kristus Yesus" .62

Namun yang membedakan Paulus dengan si pengacau, adalah si pengacau mengharuskan "melakukan hukum Taurat" perlu ditambahkan atas pembenaran karena iman dalam Kristus. Sehingga Paulus menegaskan antitesis "iman dalam Kristus" dan "melakukan hukum Taurat". Menurut Moo, Paulus disini bukan sedang mengusulkan keikutsertaan orang non-Yahudi sebagai umat Allah, melainkan bahwa orang Yahudi, tidak berbeda dengan orang non-Yahudi lainnya, adalah manusia berdosa. Hal ini dibuktikan oleh Moo dengan merujuk kepada kata "manusia" ( $(\nu \theta \rho \omega \pi \mathrm{s})$ yang berarti manusia secara umum. ${ }^{63}$ Sehingga ketaatan orang Yahudi kepada tuntutan hukum Taurat tidak akan membuat mereka dibenarkan dihadapan Allah, kecuali mereka beriman dalam Kristus. ${ }^{64}$

\footnotetext{
61 Ibid., 156.

62 Ibid., 157.

63 Ibid., 157.

64 Ibid., 157.
} 


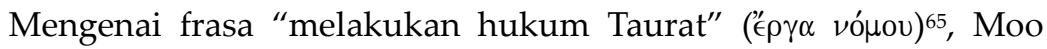
berpendapat kata ini lebih tepat ditafsirkan sebagai objective genitive, berarti "pekerjaan yang dilakukan dalam ketaatan kepada hukum Taurat" 66, sederhananya adalah: melakukan apa yang dituntut oleh hukum Taurat. Hal ini tidak mungkin terlaksana, menurut Moo, sebab manusia terkendala dengan dosa, sehingga tidak dapat "melakukan" hukum Taurat secara sempurna supaya dapat dibenarkan. ${ }^{67}$

Menurut Moo, pembacaan covenantal nomism mengenai frasa ini masih belumlah cukup. ${ }^{68}$ Sebab pembacaan sedemikian, hanya melihat zaman hukum Taurat sudah berlalu, sehingga "melakukan hukum Taurat", tidak dapat membenarkan manusia. Secara implisit, Paulus sebenarnya mengritik jemaat Galatia mengenai sesuatu yang lebih mendasar mengenai "melakukan", sebab di sini berkaitan dengan usaha pencapaian dari manusia. ${ }^{69} \mathrm{Hal}$ ini terlihat jelas ketika Paulus sengaja membandingkannya dengan prinsip dasar akan "anugerah" dalam ayat

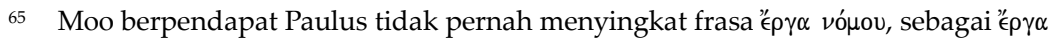
melainkan vóuov. Lih. Galatians, 27, 159.

66 Moo, Galatians, 158. Lih. juga pembahasan Moo mengenai ' Notes dari Gal. 2:16 bagian ke-3 (Galatians, 173-76); Douglas J. Moo, "'Law,' 'Works of the Law' and Legalism in Paul", 73-100.

67 Moo, Galatians, 158.

68 Menurut Moo, pandangan sedemikian sebenarnya merupakan pembacaan historis yang dipaksakan menjadi pembahasan teologis: "this having one's historical cake and eating it theologically" (Galatians, 25). Yang dimaksud dengan pembacaan historis menurut Moo adalah pembacaan menurut tradisi Yahudi pada Yudaisme Bait Allah-kedua (second-Temple Judaism): "However, many contemporary interpreters [E. P. Sanders, James D. G. Dunn, Don Garlington, N. T. Wright] insist that the problem is not with 'works' but with 'law.' Specifically, they argue that 'works of the law' must be seen in the context of Jewish views of the law and its significance in the first century." Lih. Galatians, 158.

69 Moo, Galatians, 158-59. Moo berpendapat, ada 3 alasan Paulus sedang menunjukkan bahwa frasa "melakukan hukum Taurat" dapat dimengerti sebagai permasalahan "melakukan" secara universal: (1) Paulus memperkenalkan kata "melakukan" (moŕ́ $\omega$, Gal. 3:10, 12; 5:3). Sehingga permasalahan bukan ada pada hukum Taurat, melainkan pada melakukannya; (2) Akibat dosa, maka manusia tidak mampu melakukan segala tuntutan hukum Taurat, sehingga berada dibawah kutukan hukum Taurat (Gal. 3:10, 22); (3) Paulus memperkenalkan kata "anugerah" di dalam polemik terhadap "melakukan hukum Taurat", sehingga karya keselamatan Allah hanya di dalam Kristus, dan sepenuhnya adalah persoalan anugerah, yang hanya dapat diresponsi dengan iman, dan bukan melakukan usaha apapun. Untuk lengkapnya lihat Galatians, 27-31. 
$21 . .^{70}$

Paulus merujuk kepada Mazmur 143:2 dalam ayat 16, menurut

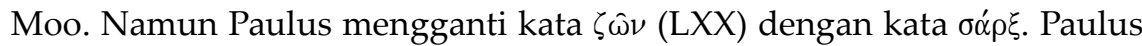
ingin menunjukkan bahwa manusia adalah "daging" sehingga jemaat Galatia tidak dapat menggenapi hukum Taurat supaya dapat dibenarkan. ${ }^{71}$

Moo mengakui bahwa kata "hukum Taurat" (vónov) dalam frasa

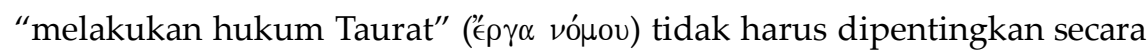
berlebihan, sehingga kehilangan signifikansi dari kata "melakukan" ('€ $\rho \gamma \alpha)$. Jika demikian, maka akan terlewatkan prinsip yang lebih mendalam mengenai antropologis dalam surat Galatia. ${ }^{72}$

Moo selanjutnya mengemukakan posisinya ketika menafsir frasa "iman Yesus Kristus" ( lebih tepat ditafsirkan sebagai objective genitive. Sebab perbedaan antara objective dan subjective, akan membawa peralihan antitesis dalam ayat 16 ini. Secara objective, akan mengontraskan secara antropologi ("melakukan" dibandingkan dengan "percaya"), sedangkan secara subjective, akan mengontraskan sejarah keselamatan (salvation-historical), yakni: "hukum Taurat dan zamannya" dibandingkan dengan "Kristus dan zaman baru" ${ }^{73}$

Alasan objective genitive ini karena: (1) Paulus menggunakan variasi kata kerja serumpun ( $\pi\llcorner\sigma \tau \epsilon u ́ \omega)$ untuk menunjukkan aktivitas percaya dari manusia, dan tidak pernah dari Kristus; (2) Hal ini juga sejalan dengan dua ayat dalam Perjanjian Lama yang dikutip Paulus yang berkaitan

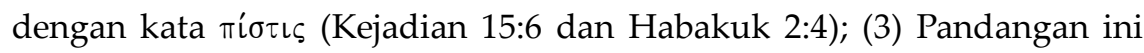

\footnotetext{
70 Moo, Galatians, 159.

71 Moo, Galatians, 159. Moo berpendapat manusia tidak dapat melakukan hukum Taurat, karena "tak berdaya oleh daging" (Rm. 8:3). Lih. Galatians, 29.

Moo menyimpulkan demikian dalam tafsiran Rm. 8:3: “'Flesh,' ... is not the flesh of our bodies, or the bodies themselves, but the "this-worldly" orientation that all people share. It is this power that the law cannot break; indeed, as Paul has made clear, the law serves to strengthen the power of sin." Lih. Douglas J. Moo, The Epistle to the Romans, 478.

72 Moo, Galatians, 160. Berbicara mengenai hal ini, Moo menambahkan bahwa doktrin sola fide dari para Reformator mendapat akar yang sah dari antitesis Gal. 2:16 ini.

73 Ibid., 160.
} 
lebih cocok dalam konteks di mana frasa ini muncul, khususnya dalam bagian: "kamipun telah percaya kepada Kristus Yesus" (Galatia 2:16) dan iman yang ditunjukkan Abraham kepada Allah (Galatia 3:6). ${ }^{74}$

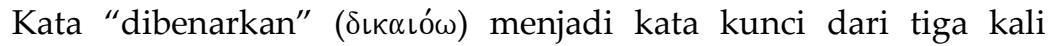
pembahasan dalam ayat ini. Menurut Moo, Paulus meresepsi kata ini dari kata Ibrani צדק. Dan kata ini dalam bentuk Hiphil berarti forensik atau yudisial. Sehingga hal tersebut, menurut Moo jauh lebih mendasar dari sekedar keikutsertaan (membership) menjadi umat Allah. Sehingga fokus dari kata ini adalah bahwa semua orang, termasuk orang Kristen Yahudi juga akan dinyatakan benar oleh Allah melalui iman dalam Kristus saja dan tidak berdasarkan "melakukan hukum Taurat" ${ }^{75}$

Oleh sebab itu, menjadi jelas Paulus menganggap salah apabila pihak Yerusalem membebankan sunat kepada orang non-Yahudi, demikian juga salah bahwa Petrus tidak mau makan bersama orang nonYahudi, dan terlebih lagi salah bahwa si pengacau memaksakan jemaat Galatia untuk tunduk di bawah hukum Taurat. ${ }^{76}$

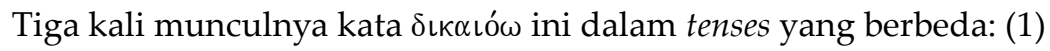
dikaiou/tai dalam bentuk present indicative, bersifat gnomic present ${ }^{77}$

74 Ibid., 160-61. Moo menjelaskan secara lebih terperinci dalam "The Faith of Christ". Lih. Galatians, 38-48.

75 Moo, Galatians, 161. Kata צדק ini, menurut Moo dapat dimengerti dalam 2 aspek: (1) kesesuaian dengan norma; (2) saling memenuhi kewajiban dari relasi tertentu yang telah dibangun. Namun menurut Moo, landasan dibalik norma ataupun relasi sebenarnya adalah karakter dari Allah (komitmen Allah untuk melakukan yang "benar" bagi ciptaan-Nya), sehingga muncul istilah "right order" atau "rightness". Sehingga Moo menyimpulkan kata ini sebagai: "These words often, and perhaps even basically, allude to the notion of doing, or being, "right," the "rightness" being determined by the particular situation in which one is placed. ... Of course, as we have noted, the "norm" by which "rightness" is measured will often be a particular relationship (e.g., the covenant), but it is perhaps not common for the language to denote that relationship as such. On the other hand, "righteousness" language will by a simple extension, often connote the status of a person who has conformed to the expected norm." (Galatians, 49-50). Untuk pembahasan Moo secara lengkap mengenai pembenaran, lihat Justification/Righteousness (Galatians, 48-62) dan Additional Notes dari Gal. 3:6 (Galatians, 189-91).

76 Moo, Galatians, 161. Moo menyimpulkan pembenaran sebagai: “Justification, one's legal standing begore God, is fully secured by faith in Christ. Nothing should be added; nothing can be added; nothing must be added." Lih. Galatians, 161-62.

77 Gnomic Present adalah present tense yang digunakan untuk membuat pernyataan terhadap fakta umum yang tidak berkaitan dengan waktu. Biasa digunakan dalam 
sehingga tidak berkaitan dengan waktu dari pembenaran; (2) $\delta \iota \kappa \alpha \iota \omega \theta \hat{\omega} \mu \in \nu$ dalam bentuk aorist subjunctive, menunjukkan tujuan apabila dikaitkan dengan kata i[na, sehingga pembenaran baru akan terjadi setelah percaya;

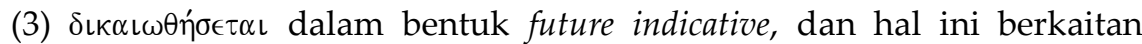
dengan waktu kedepan bagi jemaat Galatia. Sehingga hal ini mengacu kepada aspek pembenaran masa depan. ${ }^{78}$ Bentuk ini digunakan Paulus untuk menanggapi pandangan Yahudi yang meletakkan pembenaran pada penghakiman terakhir. Moo menyimpulkan bahwa pembenaran yang dimaksud oleh Paulus dalam ayat ini adalah: "Paul responds that justification is always, whatever its time, a matter of faith and not works of the law - or of works of any kind". ${ }^{79}$ Moo disini menekankan dimensi forensik dari kata "dibenarkan" di hadapan Tuhan, sehingga menekankan pembenaran dalam segala waktu.

Michael Bird menyimpulkan dengan sangat baik bahwa pembenaran yang dimaksudkan oleh Paulus dalam bagian ini mencakup pembenaran forensik dan juga penerimaan orang non-Yahudi sebagai umat Allah:

An overview of Galatians 2-3 demonstrates that Paul's articulation of justification included both a forensic declaration of righteousness and the establishment of Gentiles in the people of God. Galatians does not revolve exclusively around the issue of how to get saved but addresses the issues as to who are the people of God and what marks them out as such. All the same, Galatians moves beyond discussion of boundary markers and group membership and addresses the plight of the Jews under the law and even bondage of the human condition apart from Christ. ${ }^{80}$

perumpamaan, ataupun pepatah umum yang berlaku setiap waktu. Lih. Wallace, Greek Grammar Beyond the Basics, 523.

78 Moo, Galatians, 162.

79 Ibid., 162.

80 Michael F. Bird, The Saving Righteousness of God: Studies on Paul, Justification and the New Perspective, Paternoster Biblical Monographs (Eugene: Wipf and Stock, 2007), 119. Thielman juga berpendapat demikian: "Paul's response to this crisis is a sustained discussion of the necessary requirements for inclusion within the covenant people of God and acquittal before God on the last day. Paul's shorthand for this double-sided concept is justification." Lih. Thielman, Paul and the Law, 123. Bdk. Moisés Silva, "Faith Versus Works of Law in Galatians", dalam The Paradoxes of Paul, 246. 
Tentu pembenaran forensik menjadi hal utama, karena berkaitan dengan keberdosaan seluruh umat manusia, Yahudi maupun nonYahudi. ${ }^{81}$ Namun penerimaan non-Yahudi sebagai umat Allah juga ditekankan oleh Paulus. ${ }^{82}$

Harus diakui bahwa pembenaran mencakup aspek vertikal serta horisontal. Jika aspek horisontal diabaikan, maka pembenaran akan terlepas dari konteks sosial. Di sisi lain, terlalu menekankan aspek horisontal dan mengabaikan aspek vertikal akan mengabaikan pembenaran dalam arti apokaliptik, yudisial, dan antropologis. ${ }^{83}$

Moo juga menegaskan pembenaran jemaat Galatia hanya dapat terjadi karena "persatuan dengan Kristus" ('€ $\nu$ X "persatuan dengan Kristus" menjadi poros dari teologi Paulus. Karena dari persatuan tersebut, maka jemaat Galatia dibenarkan dan ditransformasikan. ${ }^{85}$ Pandangan ini sejalan dengan Calvin yang menekankan "persatuan dengan Kristus" sebagai yang paling mendasar bagi keselamatan manusia. ${ }^{86}$

\section{Galatia 3:10-14}

Menurut Moo, Paulus memperkenalkan kata "di bawah kutuk"

\footnotetext{
81 Bruce W. Longenecker, The Triumph of Abraham's God: The Transformation of Identity in Galatians (Nashville: Abingdon, 1998), 120-21; Bird, “Justification as Forensic Declaration and Covenant Membership", 123; Bird, The Saving Righteousness of God, 152 n. 130; Peter T. O'Brien, "Was Paul a Covenantal Nomist?" dalam The Paradoxes of Paul, 289-90; Calvin, Galatians \& Ephesians, 84.

82 Bird, The Saving Righteousness of God, 153; Mark A. Seifrid, Justification by Faith: the Origin and Development of a Central Pauline Theme (Leiden: Brill, 1992), 63.

83 Bird, The Saving Righteousness of God, 153.

84 Moo, Galatians, 165.

85 Ibid., 57. Moo menempatkan "persatuan dengan Kristus sebagai poros dari pembenaran forensik dan pengudusan: "forensic justification with transformation by viewing both as inevitable and necessary products of our being "in Christ." ... Union with Christ, not justification, lies at the heart of Paul's theology." Lih. Galatians, 55-57.

Mengenai pembahasan Moo mengenai "persatuan dengan Kristus", lih. Moo, Romans, 391-95; Douglas J. Moo, "Justification in Galatians", dalam Understanding the Times: New Testament Studies in the 21st Century, ed. Andreas J. Köstenberger dan Robert W. Yarbrough (Wheaton: Crossway, 2011), 171-78.

86 John Calvin, Institutes of the Christian Religion, ed. John T. McNeill, trans. Ford Lewis Battles, 2 vols. (Philadelphia: Westminster, 1960), III.i.1, III.xi.10.
} 


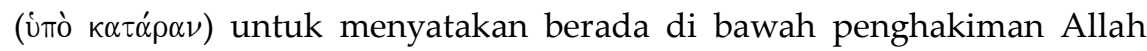
karena gagal hidup sesuai dengan tuntutan perjanjian Allah. ${ }^{87}$ Hal ini dilakukan oleh Paulus dengan mengutip Ulangan 27:26, walaupun pengunaan Paulus dalam ayat 10 sedikit berbeda dengan LXX dan MT, namun hal tersebut tidak membawa pengaruh yang signifikan. ${ }^{88}$

Berkenaan dengan "berada di bawah kutuk", Jason C. Meyer secara tepat menyimpulkan bahwa terdapat tiga permasalahan dengan hukum Taurat, sehingga menyebabkan "kutuk": (1) Masalah antropologis: pada kenyataannya manusia berada di bawah ikatan dosa, sehingga manusia tidak mungkin dapat menaati hukum Taurat sepenuhnya; (2) Masalah ontologis: hukum Taurat secara intrinsik tidak memberikan kemampuan kepada manusia untuk menyelesaikan permasalahan antropologis yang diturunkan Adam; (3) Masalah kronologis: pada zaman baru, pendamaian yang disediakan hukum Taurat sudah tidak berlaku. ${ }^{89}$

"Segala" ( $\pi \hat{\alpha} \sigma \nu \nu)$ yang tertulis dalam kitab hukum Taurat harus dilakukan supaya kutuk tersebut dapat terhindarkan, demikian menurut

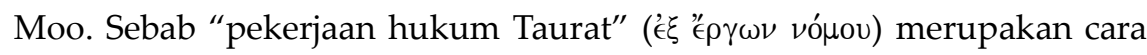
umum untuk mengacu kepada "melakukan" hukum Taurat. Dan pada kenyataannya, tidak ada orang yang dapat melakukan segala sesuatu yang tertulis dalam hukum Taurat..$^{90}$ Hal ini bukan karena era hukum Taurat sudah berlalu, karena kehadiran Kristus membawa era baru. Namun menurut Moo, Paulus sedang mempermasalahkan hal yang lebih mendasar mengenai "melakukan". Sebab "melakukan" inilah yang menurut Paulus adalah sesuatu yang tidak mungkin bagi manusia. ${ }^{91}$

\footnotetext{
87 Moo, Galatians, 201.

88 Ibid., 201. Menurut Moo perbedaan ayat 10 dengan LXX dan MT adalah minor, dan mungkin dipengaruhi oleh ayat-ayat paralel dari Kitab Ulangan. Lih. pembahasan Moo dalam Additional Notes dari Gal. 3:10 (Galatians, 218-19).

89 Jason C. Meyer, The End of the Law: Mosaic Covenant in Pauline Theology (Nashville, TN: B\&H Academic, 2009), 153-57.

90 Moo, Galatians, 202-3.

91 Ibid., 203-4. Lih. juga Douglas J. Moo, "Paul's Reading of Deuteronomy: Law and Grace", dalam For Our God Always: Studies on the Message and Influence of Deuteronomy in Honor of Daniel I.Block, ed. Jason S. Derouchie, Jason Gile, dan Kenneth Turner (Winona
} 
Selain itu, Paulus juga menyatakan bahwa setiap individu (berbeda dengan konteks Kitab Ulangan yang ditujukan kepada umat

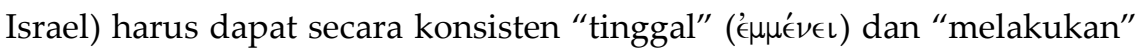

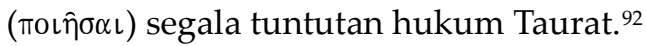

Sekalipun orang Kristen Yahudi dapat menyangkal bahwa tuntutan "sempurna" tidak pernah ada dalam pemikiran Yudaisme. Dan hukum Taurat sendiri menyediakan sarana penebusan bagi yang tidak menjalankannya secara "sempurna". Menurut Moo, penggunaan kata "segala" ( $\pi \hat{\alpha} \varsigma)$ secara berulang dalam Kitab Ulangan menjadi landasan bagi Paulus untuk menyimpulkan bahwa tuntutan "sempurna" atau "penuh" terhadap hukum Taurat adalah keharusan apabila ingin menghindarkan diri dari kutukan. Dalam hal ini, salib Kristus sebagai satu-satunya sarana penebusan dan yang telah sempurna. ${ }^{93}$ Dengan demikian, Moo menekankan aspek antropologi, akan aspek keberdosaan manusia sebagai alasan ketidakmampuan menaati hukum Taurat secara sempurna.

Paulus selanjutnya mengutip Habakuk 2:4 untuk melanjutkan pembahasan mengenai apa yang tidak dapat dicapai oleh hukum Taurat. Dalam konteks awal Habakuk, umat Israel dipanggil untuk tetap setia meskipun dalam keadaan yang kacau dan suram, serta "hidup" berdasarkan kasih setia Tuhan dan pengharapan yang dinyatakan oleh Tuhan. Di sini Paulus mengaitkan "hidup" kepada signifikansi teologis yang lebih mendalam, karena berkaitan dengan "membenarkan" (Galatia $3: 21) .{ }^{94}$

Menurut Moo, baik Habakuk maupun Paulus, kata "benar"

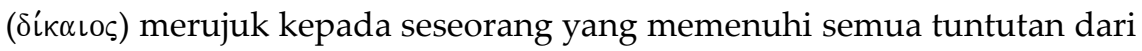
Allah, namun Paulus menggunakan kata ini secara spesifik untuk status

Lake: Eisenbrauns, 2013), 391-400.

92 Moo, Galatians, 204.

93 Ibid., 204.

94 Ibid., 206. Menurut Moo, penulis PB dalam mengutip PL, ditandai dengan makna yang lebih mendalam dari makna awal (Galatians, 207). Lih. juga Douglas J. Moo, "The Problem of Sensus Plenior", dalam Hermeneutics, Authority, and Canon, ed. D. A. Carson dan J. D. Woodbridge (Grand Rapids: Zondervan, 1986), 179-211. 


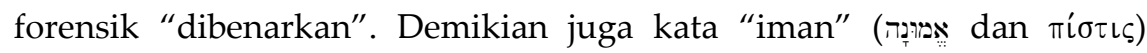
menurut Habakuk maupun Paulus adalah karakter yang dibutuhkan oleh umat Allah untuk pengharapan masa depan. ${ }^{95}$

Namun ada perbedaan penggunaan kata "hidup" bagi Habakuk dan Paulus. Habakuk merujuk kepada "menghidupi kehidupan". Bagi Paulus, "hidup" yang dimaksud memiliki nuansa soteriologis. Hal ini bukan berarti Paulus memaksakan makna baru, melainkan merupakan penerapan yang sah terhadap berita kenabian dengan menitikberatkan pada iman kepada Allah. ${ }^{96}$

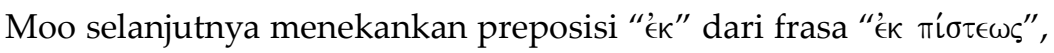
untuk menunjukkan ekspresi teknis dari preposisi ini (Galatia 3:7, 8, 9, 11, dan 12). Dengan demikian, Paulus mengontraskan antara "dari

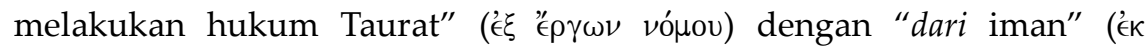

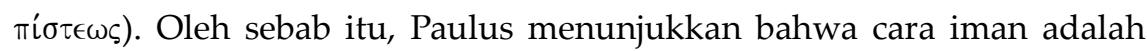
berbeda dari cara hukum Taurat. ${ }^{97}$

Selanjutnya Paulus mengutip dari Imamat 18:5, yang dalam konteks awal berkenaan dengan serangkaian perintah khusus berkaitan dengan relasi seksual (Imamat 18:6-23). Dengan demikian, Imamat 18:5 merupakan janji berkat bagi ketaatan. Ayat ini juga sering dikutip dalam Perjanjian Lama (Yehezkiel 20:11, 13, 21; Nehemia 9:29) dan tradisi Yudaisme dengan konotasi spiritual, bahkan secara eksplisit berkaitan dengan hidup kekal. ${ }^{98}$

Paulus disatu sisi mengutip Habakuk 2:4 untuk mengatakan "iman" adalah sarana bagi hidup. Sedangkan disisi lain mengutip Imamat 18:5 untuk mengatakan yang "melakukan" hukum Taurat akan hidup karenanya. Bukankah berarti Habakuk 2:14 dan Imamat 18:5

\footnotetext{
95 Moo, Galatians, 207. Moo berpendapat, walaupun kata ini secara literal berarti "keteguhan" atau "kemantapan keyakinan". Namun keteguhan tersebut tertuju kepada Allah, sehingga tepat apabila Paulus menamainya sebagai iman (Galatians, 207). Lih. juga Additional Notes dari Gal. 3:11 (Galatians, 219-20).

96 Moo, Galatians, 207. Lih. juga Additional Notes dari Gal. 3:11 (Galatians, 219-20).

97 Ibid., 208.

98 Ibid., 208. Menurut Moo, Targum Onqelos dan Targum Pseudo-Jonathan menggunakan frasa "hidup kekal." Lih. juga Additional Notes dari Gal. 3:12 (Galatians, 220-21).
} 
bersifat kontradiksi? Tentu tidak, menurut Moo. Imamat 18:5 merupakan kesimpulan dari "hidup" dalam perjanjian Allah yang dijanjikan kepada Israel. Sedangkan Habakuk 2:4 merupakan kesimpulan dari seluruh pengajaran Perjanjian Lama mengenai "hidup" yang benar di hadapan Allah. Imamat 18:5 adalah janji yang sah mengenai hidup sejati bersama dengan Allah, namun karena keberdosaan manusia, maka tidak pernah menjadi kenyataan. ${ }^{99}$

Dengan demikian, Paulus menegaskan dengan jalan iman, maka manusia beroleh "hidup". Sehingga jemaat Galatia tidak perlu terhasut untuk menambahkan ketaatan hukum Taurat kepada "iman dalam Kristus". 100 Moo selanjutnya menambahkan: "Faith, Paul implies, is the only instrument by which justification/ life can be attained: whether at the beginning of one's Christian experience or at its end". ${ }^{101}$

Paulus selanjutnya mengungkit kembali kata "kutuk". Kata "kutuk" merujuk kepada penghakiman Allah, dan penghakiman tersebut berupa pengasingan dari tanah dan umat Allah. Namun disini "kutuk" tersebut dikenakan kepada Kristus. ${ }^{102}$

Dengan mengutip Ulangan 21:22-23, Paulus menyiratkan bahwa Kristus menderita "kutuk" karena tergantung di atas kayu salib akibat dosa-tetapi karena dosa orang lain, bukan karena dosa-Nya. Dengan demikian, Kristus menderita pengasingan dari umat Allah, bahkan terpisah dari Allah Bapa (Markus 15:34), supaya manusia yang terasing karena dosa, dapat dibawa kembali kepada Allah. ${ }^{103}$ Dengan demikian, Moo menekankan aspek vertikal dari penebusan Kristus di kayu salib.

\section{Galatia 3:19-22}

Menurut Moo, Paulus tidak melihat bahwa melakukan hukum Taurat adalah sesuatu yang buruk. Di tempat lain, Paulus menjelaskan

\footnotetext{
99 Moo, Galatians, 209.

100 Ibid., 209.

101 Ibid., 209.

102 Ibid., 210.

103 Ibid., 214. Lih. juga Additional Notes dari Gal. 3:13 bagian ke-2 (Galatians, 222-23).
} 
bahwa jemaat Kristen Yahudi memperoleh hidup baru di dalam Kristus, serta tidak dilarang untuk mengikuti hukum Taurat (Roma 14:1-15:13; 1 Korintus 9:20-22). Namun dalam surat Galatia, Paulus sangat keberatan dengan: (1) ketaatan kepada hukum Taurat sebagai syarat bagi pembenaran, baik untuk masa ini maupun masa yang akan datang; dan (2) jemaat non-Yahudi diharuskan untuk menjalankan hukum Taurat. ${ }^{104}$ Hal ini senada dengan Calvin yang melihat bahwa baik janji Allah dan hukum Taurat bukanlah sesuatu yang harus dipertentangkan, karena keduanya berasal dari rencana Allah. ${ }^{105}$

Yang menjadi permasalahan bagi Paulus ialah si pengacau menempatkan hukum Taurat dan janji Allah kepada Abraham pada tataran yang sama, sehingga hukum Taurat sebagai keniscayaan di atas janji Allah. Hal ini dilihat secara berbeda oleh Paulus, sebab hukum Taurat tidak dapat mengubah perjanjian Allah kepada Abraham. Dengan demikian, Paulus melihat hukum Taurat memiliki dua fungsi: (1) Hukum Taurat memperburuk dan mengungkapkan dosa, serta tidak dapat memberikan hidup (Galatia 3:19a, 21, 22a); (2) Hukum Taurat dimaksudkan hanya untuk sementara hingga kehadiran Mesias (Galatia $3: 19 b, 23-25) \cdot{ }^{106}$

Menurut Moo, Paulus sengaja menekankan aspek temporal dari hukum Taurat. Hal ini bertentangan dengan tradisi Yahudi yang berpendapat bahwa hukum Taurat ini kekal. Paulus, disatu sisi menekankan bahwa hukum Taurat ada permulaan, karena “ditambahkan" setelah 430 tahun perjanjian Allah dengan Abraham. Di sisi lain, hukum Taurat memiliki akhir, yaitu hingga "datang keturunan yang dimaksud oleh janji itu". ${ }^{107}$

Selanjutnya Moo memaparkan kemungkinan penafsiran preposisi $\chi \alpha \dot{\rho} \iota \nu$ ini. Secara stuktur, preposisi ini bisa mengindikasikan tujuan ("demi untuk") dan alasan ("oleh karena"). Dan Paulus sendiri

\footnotetext{
104 Moo, Galatians, 224.

105 Calvin, Galatians E Ephesians, 104.

106 Moo, Galatians, 224-25.

107 Ibid., 232-33.
} 
menggunakan kedua bentuk arti tersebut (Titus 1:11; Efesus 3:1). Moo membagi menjadi empat tafsiran berkaitan dengan kata ini. ${ }^{108}$ Dan Moo berpendapat, Paulus cenderung kepada penafsiran "demi untuk", sebab dalam terang Roma 5:20: "hukum Taurat ditambahkan, supaya pelanggaran menjadi semakin banyak." 109

Penggunaan kata "pelanggaran" ( $\pi \alpha \rho \alpha ́ \beta \alpha \sigma \iota \varsigma)$ ini menjadi penting, menurut Moo. Sebab kata ini merujuk kepada pelanggaran terhadap hukum yang sudah diketahui. Sehingga hukum Taurat ditambahkan bukan untuk dosa di masa sebelum hukum Taurat, melainkan dosa setelah hukum Taurat. Dengan demikian, hukum Taurat mengubah dosa menjadi pelanggaran. Dosa sendiri perlu dihukum oleh Allah, namun pelanggaran terlebih lagi, sebab melibatkan pelanggaran terhadap hukum yang sudah disadari. ${ }^{110}$

Paulus mengaitkan pemberian hukum Taurat dengan "malaikat" dan "pengantara". Menurut Moo, perantaraan ini dimaksudkan Paulus untuk mengontraskan dengan ayat 20, dimana dikatakan "seorang pengantara bukan hanya satu, Allah adalah satu". Tentu tidak diragukan lagi bahwa pengantara tersebut adalah Musa. ${ }^{111}$ Namun mengapa pemberian hukum Taurat dibandingkan dengan "Allah adalah satu"? Disini Moo berpendapat, terdapat tiga kemungkinan penjelasan: (1) Tafsiran difokuskan pada frasa "seorang pengantara bukan hanya satu" dibandingkan dengan banyak malaikat ( $\dot{\alpha} \gamma \gamma^{\prime} \epsilon \omega \nu$, dalam bentuk jamak). Dengan demikian membuat pemisahan jelas antara Allah dan hukum Taurat, sebab terdapat dua sumber yang berbeda; (2) Difokuskan kepada

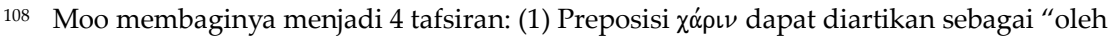
karena", dalam artian fungsi hukum Taurat adalah menyingkapkan dosa, sehingga manusia menyadari keberdosaannya; (2) Diartikan sebagai "oleh karena", dalam artian relasi hukum Taurat dengan dosa. Dalam arti negatif, bagaimana hukum Taurat berurusan dengan dosa. Secara positif, bagaimana hukum Taurat menghambat dan mengobatinya; (3) Diartikan sebagai "demi untuk", dalam artian hukum Taurat memprovokasi dosa; (4) Diartikan sebagai "demi untuk", dalam artian hukum Taurat memperparah keseriusan dosa dan menyingkapkan natur dosa yang sesungguhnya, membuat dosa menjadi pelanggaran. Lih. Galatians, 233-34.

109 Moo, Galatians, 234; Moo, Romans, 347-48.

110 Moo, Galatians, 234.

111 Ibid., 235.
} 
kata "satu" ( $\epsilon \hat{i} \zeta$ ) dalam ayat 20, sehingga mengontraskan ada dua pihak dalam pengantaraan ini. Dalam tafsiran ini kedua belah pihak perlu bekerja sama supaya pemberian hukum Taurat menjadi efektif, yaitu: pemberi (malaikat dan Musa) dan penerima (umat Israel). Sedangkan perjanjian Allah, merupakan inisiatif dari Allah sepihak; (3) Difokuskan kepada kata "satu" ( $\epsilon \hat{i} \varsigma)$, namun dikaitkan dengan benih Abraham yang tunggal, yaitu Kristus (Galatia 3:16). Dengan demikian, menekankan "kesatuan umat Allah" (termasuk orang non-Yahudi). Sehingga penekanan kepada perjanjian Abraham yang tunggal, dan Musa bukanlah pengantara dari perjanjian ini. ${ }^{112}$

Setelah memberikan pertimbangan akan tafsiran tersebut, Moo memutuskan tafsiran yang kedua menjadi tafsiran yang lebih tepat. Sebab menurut Moo, esensi dari pengantara di dalam memberikan hukum Taurat mengimplikasikan adanya unsur keterlibatan dari manusia yang sangat bertentangan dengan karakter dari perjanjian yang adalah anugerah. ${ }^{113}$

Paulus melanjutkan dengan pertanyaan retorika: "Kalau demikian, bertentangankah hukum Taurat dengan janji-janji Allah?" Dengan segera Paulus menimpali "Sekali-kali tidak". Menurut Moo, Paulus disini menolak kontradiksi dari hukum Taurat dan janji Allah. Sebab, kata

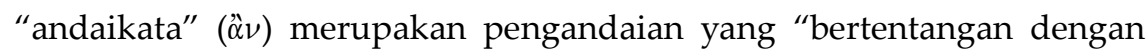
fakta", menurut Moo. Sehingga Paulus mengandaikan "hukum Taurat" dapat "menghidupkan", dan apabila dapat "menghidupkan", berarti

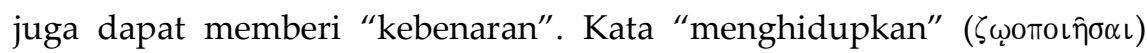
memiliki nuansa soteriologi, sehingga berarti kehidupan akhir atau hidup kebangkitan (Roma 8:11; 1 Korintus 15:22, 36, 45). ${ }^{114}$

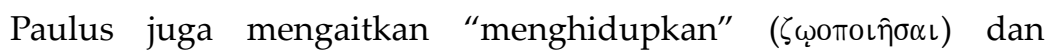

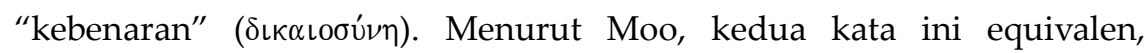
"menghidupkan" fokus kepada proses, sedangkan "kebenaran" fokus

\footnotetext{
112 Ibid., 236-37.

113 Ibid., 237.

114 Ibid., 237-38.
} 
kepada status yang dihasilkan. ${ }^{115}$

Menurut Moo, alasan hukum Taurat tidak dapat "menghidupkan" karena tidak ada seorangpun dapat memenuhi tuntutan hukum Taurat. Hal ini disebabkan oleh realita keberdosaan manusia. ${ }^{116}$ Dengan demikian, tidak terdapat konflik antara hukum Allah dan janji Allah. Sebab Allah berelasi dengan Abraham melalui sarana perjanjian dan perjanjian tersebut hanya memerlukan respon iman supaya memperoleh pembenaran dan kehidupan eskatologi. Sehingga posisi hukum Taurat di dalam sejarah keselamatan, sebagai tambahan untuk mengurus perjanjian yang telah diteguhkan Allah kepada Abraham dan benih (tunggal) Abraham. ${ }^{117}$

Sebab "Kitab Suci", secara fokus adalah Perjanjian Lama secara keseluruhan, sudah mengurung segala sesuatu di bawah kekuasaan dosa, melalui hukum Taurat. Menurut Moo, "segala sesuatu” ( $\tau \dot{\alpha} \pi \alpha \dot{\nu} \tau \alpha)$ yang dimaksud bukan hanya manusia saja, melainkan seluruh kosmos. Hal ini selaras dengan pembaharuan yang akan dibahas oleh Paulus dengan bahasa "ciptaan baru" (Galatia 6:15). ${ }^{118}$

Frasa "di bawah dosa" (ímò $\dot{\alpha} \mu \alpha \rho \tau i ́ \alpha \nu$ ) mengacu kepada segala ciptaan di bawah kuasa dari dosa. Menurut Moo, Paulus sendiri melihat dosa sebagai "as a power that exerts its influence over the world, with

\footnotetext{
115 Ibid., 238.

116 Ibid., 239.

117 Moo, Galatians, 239. Moo merangkumkan relasi hukum Taurat dan janji Allah sedemikian: "From soteriological perspective, then, the law plays a subsidiary role, entering into salvation history to 'administer' the promise covenant that God established with Abraham and his 'seed'" (Galatians, 239). Berkaitan dengan relasi perjanjian Abraham (Abrahamic covenant) dan perjanjian Musa (Mosaic covenant), Moo berpendapat: "Our comments about the subordinate and, in a sense, nonsoteriological nature of the Mosaic covenant are focused on the way Paul presents the matter here in Galatians. It must always be remembered that the polemical nature of the letter leads Paul to stress certain aspects of the salvation-historical relationship while neglecting others. ... He therefore presents the law, and by extension the Mosaic covenant, as a matter of works and not of faith (e.g., 3:1112). He does not thereby deny that the Pentateuch and even, in one sense, the law itself call for faith (e.g., the "circumcision of the heart"). But for Paul it is a matter of definition that "law" involves "doing" in distinction from believing. From his standpoint at the "turn of the ages," Paul therefore speaks about the law "in itself" and contrasts it with the Abrahamic covenant." Lih. Galatians, 246.

118 Ibid., 239.
} 
particular focus in this context on the condemnation that results from sin's domination". 119

\section{Galatia 5:1-6}

Bentuk dative dari "merdeka" ( $\tau \hat{n}$ ' $\epsilon \in \in \cup \theta \in \rho i \alpha$ ), menurut Moo berarti merujuk kepada tujuan atau hasil akhir. Sehingga apabila kata ini digunakan dalam konteks dapat dimengerti sebagai "Kristus telah memerdekakan kita supaya kita sungguh-sungguh merdeka." Kemerdekaan yang dimaksud oleh Paulus menggunakan bahasa penebusan dalam Galatia 3:13 dan 4:5, sehingga merupakan kemerdekaan dari hukum Taurat. ${ }^{120}$ Di sini Moo tidak membedakan secara jelas apakah "merdeka" dari keseluruhan hukum Taurat atau legalisme dari hukum Taurat.

Moo mengakui bahwa Paulus mengikuti pola indikatif-imperatif dari penulis Perjanjian Baru, dan di sini Paulus meminta jemaat Galatia

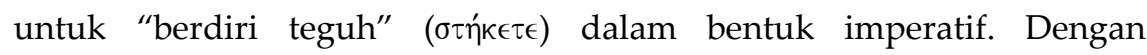
demikian menasihati jemaat Galatia untuk berpegang kepada keistimewaan dan berkat yang mereka terima dalam era baru dari keselamatan. ${ }^{121}$

Paulus mengecam jemaat Galatia yang berencana untuk "menyunatkan" ( $\epsilon \rho \iota \tau \epsilon \in \mu \nu \eta \sigma \theta \epsilon$, dalam bentuk present) diri mereka. Menurut Moo, hal ini terlihat pada Galatia 4:10, ketika mereka sudah mulai mengambil langkah awal untuk "memelihara" ( $\pi \alpha \rho \alpha \tau \eta \rho \epsilon \hat{\sigma} \theta \epsilon$, dalam bentuk present) hari-hari, bulan-bulan, masa-masa, dan tahuntahun tertentu. Dan tiba kepada langkah berikutnya dan yang menentukan untuk "menyunatkan" diri mereka. ${ }^{122}$ Dan apabila mereka "menyunatkan" diri mereka, maka Paulus memperingatkan bahwa "Kristus sama sekali tidak akan berguna bagimu". ${ }^{123}$

\footnotetext{
119 Ibid., 240.

120 Ibid., 319-20.

121 Ibid., 320.

122 Ibid., 321.

123 Ibid., 321.
} 
Moo berpendapat, penolakan terhadap "sunat" merupakan permasalahan kontekstual bagi Paulus. Disatu sisi, Paulus sangat menentang "sunat" ini sebagai sarana untuk mendapatkan keanggotaan umat Allah. Disisi lain, Paulus tidak menetang "sunat" apabila hal tersebut tidak menjadi syarat keselamatan. Dengan demikian, Paulus bukan menentang sunat dalam arti pelaksanaannya secara lahiriah, melainkan signifikansi ritual dari sunat dalam konteks Yudaisme abad pertama. ${ }^{124}$

Paulus menegaskan bahwa mereka yang menyunatkan diri “wajib melakukan seluruh hukum Taurat". Menurut Moo, sunat ini berkaitan dengan "tinggal dalam segala sesuatu yang tertulis dalam hukum Taurat" (Galatia 3:10). Dimana dalam ayat ini maupun Galatia 3:10, keduanya berbicara mengenai "melakukan" hukum Taurat dan menekankan pentingnya "seluruh" hukum Taurat. Dengan demikian, Paulus ingin mengatakan tidak ada seorangpun yang dapat "melakukan" hukum Taurat secara sempurna. Apabila jemaat Galatia tetap ingin menyunatkan diri mereka, mereka sudah "terkutuk", karena kuasa dosa menghalangi mereka untuk menjalankan seluruh hukum Taurat untuk mendapatkan pembenaran dari Allah. ${ }^{125}$

Tentu tradisi Yahudi dapat membantah anggapan bahwa "tidak boleh ada pelanggaran terhadap hukum Taurat sedikitpun". Bagi mereka pelanggaran terhadap hukum Taurat dapat didamaikan melalui sarana ketentuan hukum Taurat sendiri. Namun disini Moo menanggapi, bahwa dalam zaman baru yang diinaugurasi oleh Kristus melalui kematian dan kebangkitan-Nya, telah meniadakan validitas korban dari zaman lama. Sekarang hanya tersedia dua pilihan pada era Kristen: (1) dibenarkan dalam Kristus melalui iman; atau (2) mendapatkan pembenaran melalui melakukan hukum Taurat, atau hukum lainnya. Namun Moo segera menambahkan, kuasa dosa atas manusia, membuat "perbuatan" manusia tidak memadai untuk meneguhkan pembenaran dirinya dihadapan Allah.

\footnotetext{
124 Ibid., 322.

125 Ibid., 324.
} 
Sehingga yang dipermasalahkan oleh Paulus adalah sesuatu yang lebih fundamental dan universal, melampaui persoalan sejarah. ${ }^{126}$

Paulus selanjutnya memberikan dua peringatan keras secara retoris bagi mereka yang tetap mengharapkan kebenaran karena hukum Taurat, yaitu: lepas dari Kristus dan memungkiri anugerah Allah. Kata "lepas" (к $\alpha \alpha \rho \gamma \epsilon \epsilon \omega)$ ini untuk mengingatkan bahwa jemaat Galatia dahulu pernah “dilepaskan" dari hukum Taurat supaya dapat bersatu dengan Kristus dan dapat melayani dengan keadaan baru menurut Roh Kudus (Roma 7:5-6). Namun sekarang mereka hendak melakukan pembalikkan, untuk "lepas" dari Kristus dan kembali kepada hukum Taurat. ${ }^{127}$

Demikian halnya juga, terlepas dari Kristus, berarti jemaat Galatia

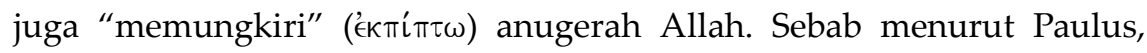
konsep anugerah adalah: "God is free and unconstrained and that all that he does for his created beings is therefore given freely and without conditions". ${ }^{128}$ Dengan demikian, jelas bahwa jemaat Galatia di dalam menuntut hukum Taurat adalah salah, karena berusaha mendapat pembenaran di hadapan Allah melalui usaha manusia. Usaha tersebut jelas-jelas bertentangan dengan anugerah Allah. ${ }^{129}$

Moo berpendapat ayat 5 dan 6 ini merupakan klimaks dari argumentasi dalam surat Galatia, karena mempertemukan kata-kata kunci dalam surat ini: kebenaran, iman, dan Roh sebagai sarana supaya pembenaran dapat diperoleh dan dipertahankan, dan kasih sebagai ekspresi dan wujud dari iman. ${ }^{130}$

Menurut Moo, Paulus menggunakan kata "kami menanti dengan sangat" ( $\dot{\alpha} \pi \epsilon \kappa \delta \in \chi o ́ \mu \epsilon \Theta \alpha)$ untuk antisipasi eskatologi. Ditambah lagi dengan

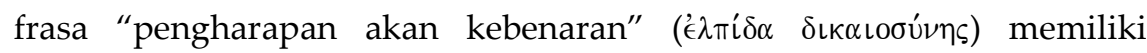
elemen pengharapan kebenaran forensik di masa yang akan datang. ${ }^{131}$

\footnotetext{
126 Ibid., 324-25.

127 Ibid., 326.

128 Moo, Galatians, 326. Lih. juga pembahasan Moo mengenai Rm. 4:4-5 di Romans, 263-66.

129 Moo, Galatians, 326-27.

130 Ibid., 327.

131 Ibid., 328.
} 


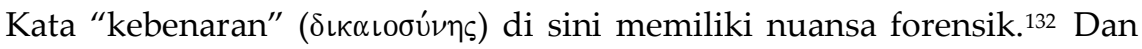
"kebenaran" ini menjadi isi dari pengharapan $\left(€ \lambda\langle i \delta \alpha \alpha)\right.$ jemaat Galatia. ${ }^{133}$

Dengan demikian, Paulus menasihatkan jemaat Galatia akan pembenaran yang akan datang. Sehingga bukan hanya "awal masuk" dibenarkan, melainkan bisa "mempertahankan" status pembenaran mereka, hingga tetap "benar" pada penghakiman terakhir.134

Menurut Moo, Paulus dalam pasal-pasal sebelumnya menitikberatkan kepada pengalaman terhadap "Roh". Namun dalam pasal 5:13-6:10, Paulus fokus kepada karya dari Roh Kudus. Dengan demikian, Paulus mengantisipasi hal tersebut dengan mengutip "Roh" dalam ayat ini. Menurut Paulus, kehidupan Kristen adalah kehidupan yang mengaplikasikan dan menghidupi kuasa Roh sambil menunggu konfirmasi status pembenaran mereka di hadapan Allah. ${ }^{135}$

Paulus selanjutnya menekankan perlunya iman sejati dimanifestasikan dalam perbuatan melalui kasih. Namun kasih tersebut bukan syarat bagi iman, seakan-akan kasih itu menjadi keharusan untuk iman dapat dibenarkan. Oleh sebab itu, menurut Moo, merupakan alasan

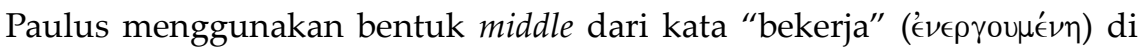
sini. ${ }^{136}$

132 Moo, Galatians, 327. Mengenai "pembenaran”, Moo berpendapat demikian: “In my view, however, every occurrence of dik- language in Galatians relates to the doctrine of justification; and, in Galatians, justification is forensic. The issue in the letter is all about status before God." Lih. Moo, "Justification in Galatians", 163.

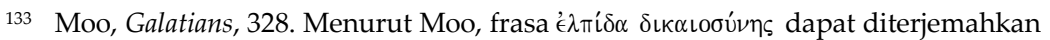
sebagai: (1) Secara source genitive, yang berarti "pengharapan yang dilandaskan kepada kebenaran"; (2) Secara appositional atau objective genitive, yang berarti "pengharapan yang benar". Moo berpendapat, secara linguistik objective genitive lebih sesuai dengan makna frasa yang sama disejumlah surat Paulus dan tentunya dalam konteks ayat ini. Lih.

Galatians, 328 n. 13.

134 Moo, Galatians, 61, 328. Moo menyimpulkan ayat 5 demikian: "If righteousness here indeed refers to a future dimension of justification, then Paul affirms quite clearly that faith is the means not only of entering into relationship with God, but also of maintaining that relationship and of confirming that relationship on the day of judgment" Lih. Galatians, 329. 135 Moo, Galatians, 329. Moo berpendapat peran Roh Kudus menjadi poros bagi pengajaran Paulus mengenai ketaatan orang percaya: "A deep-seated confidence in the Spirit's power to transform believers lies at the heart of Paul's teaching about Christian obedience; that confidence in the Spirit should be a hallmark of any faithful teaching about the nature of the Christian life." Lih. Galatians, 329.

136 Moo, Galatians, 330. 
Moo berpendapat, dalam ayat 6 ini pengertian Paulus akan iman adalah aktif dan berkuasa. "Iman" menjadi kata kunci dalam Galatia 2:16-4:31, sedangkan "kasih" menjadi tema yang menonjol dalam Galatia

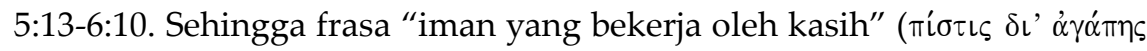

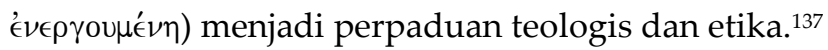

Calvin berpendapat bahwa iman yang membenarkan tidak berdiri "sendiri", melainkan disertai dengan pekerjaan baik. ${ }^{138}$ Namun Calvin membedakan dengan sangat jelas antara iman dan kasih, tanpa mencampuradukkan keduanya. ${ }^{139}$

\section{Galatia 5:13-15}

Menurut Moo, argumen dasar dari bagian ini adalah Roh Kudus memampukan orang percaya untuk mengatasi kuasa daging dan menstimulasi kasih kepada sesama, sehingga dengan demikian menggenapi hukum Taurat. ${ }^{140}$

Paulus memulai perikop ini dengan menggunakan tema "merdeka" secara efektif untuk membuat transisi ke dalam pembahasan etika yang mendominasi Galatia 5:13-6:10. Menurut Paulus, kata "merdeka" (' $\langle\epsilon \in \theta \epsilon \rho i ́ \alpha)$ ini berarti lepas dari kuasa pada zaman lama: dari dosa, "roh-roh dunia", allah palsu, dan juga terhadap hukum Taurat (Galatia 3:22-25; 4:3, 8-9, 24-31). Namun “kemerdekaan" ini bukanlah bersifat otonomi, melainkan kebebasan yang hakiki yang dirancang Allah dari semula. Oleh sebab itu, "merdeka" yang dimaksud Paulus adalah untuk hidup mengasihi dan berkorban bagi sesama. ${ }^{141}$

\footnotetext{
137 Ibid., 331.

138 "It is not our doctrine that the faith which justifies is alone; we maintain that it is invariably accompanied by good works; only we contend that faith alone is sufficient for justification." Lih. Calvin, Galatians \& Ephesians, 152.

139 "When you are engaged in discussing the question of justification, beware of allowing any mention to be made of love or of works, but resolutely adhere to the exclusive particle. Paul does not here treat of justification, or assign any part of the praise of it to love." Lih. Calvin, Galatians \& Ephesians, 152.

140 Moo, Galatians, 339.

141 Ibid., 343.
} 
"Kemerdekaan" jemaat Galatia, menurut Paulus, jangan diberi kesempatan untuk "daging”. Kata "daging” ( $\sigma \alpha ́ \rho \xi)$, menurut Moo, mencakup spektrum yang luas mulai dari berkenaan dengan fisik/netral hingga kepada spirtual/negatif. Berkenaan dengan fisik dapat dimengerti sebagai: (1) jaringan tubuh manusia; (2) keseluruhan tubuh manusia; (3) manusia secara utuh; (4) kondisi manusia secara umum, namun bukan berkaitan dengan dosa; (5) keterbatasan manusia. Berkenaan dengan spiritual dapat dimengerti sebagai: keterbatasan kondisi manusia yang sudah berdosa. Dalam hal ini, Moo berpendapat, "daging" ( $\sigma \alpha ́ \rho \xi)$ disini dimengerti sebagai aspek manusia yang bertentangan dengan Roh, dan manusia diperhadapkan dengan pergolakan diantara kedua kekuatan tersebut. ${ }^{142}$

Dengan mengikuti Martyn, Moo berpendapat bahwa "kemerdekaan" tersebut tidak berarti otonomi, melainkan bebas dari sebuah perbudakan berpindah kepada perbudakan yang lain, sehingga "kemerdekaan" Kristen adalah akan memimpin kepada bentuk "perbudakan" Kristen. ${ }^{143}$ Oleh sebab itu, Paulus meminta jemaat Galatia untuk "melayani" ( $\delta o u \lambda \epsilon u ́ \omega)$ seorang akan yang lain dalam kasih.

Konotasi perbudakan tersebut dipadukan dengan kata "kasih"

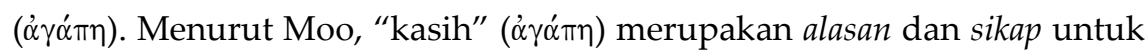
melayani sesama. Dan "kasih" ini menuntut adanya relasi timbal balik di dalam sebuah komunitas, sehingga Paulus meminta jemaat Galatia untuk

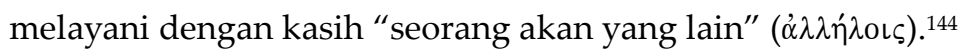

Menurut Paulus, hukum Taurat "digenapi" ( $\epsilon \epsilon \pi \lambda \eta ́ \rho \omega \tau \alpha \iota$, dalam bentuk perfect passive) oleh kasih. Ini berarti hukum kasih dalam Imamat 19:18 menggenapi seluruh hukum Taurat. Menurut Moo, perintah ini merupakan salah satu perintah dari dua hukum yang terutama yang disimpulkan oleh Tuhan Yesus mengenai hukum Taurat (Matius 22:39//Markus 12:31//Lukas 10:27). Dengan demikian, Paulus meresepsi

\footnotetext{
142 Ibid., 343-44.

143 Moo, Galatians, 344; J. Louis Martyn, Galatians: A New Translation with Introduction and Commentary, Anchor Yale Bible Commentaries: Vol. 33A (New York: Doubleday, 1997), 485.

144 Moo, Galatians, 345.
} 
tradisi Yesus dari saksi mata, yang berakar pada Yesus sendiri. ${ }^{145}$

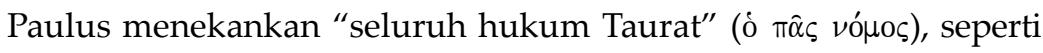

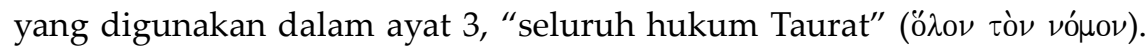
Menurut Moo, Paulus mengacu kepada keutuhan dari hukum Taurat. ${ }^{146}$

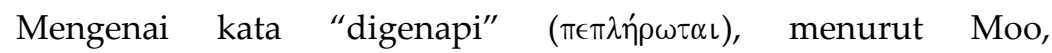
kebanyakan penafsir menafsir sebagai "melakukan" hukum Taurat. Namun menurut Moo, hal ini bukan sekedar "melakukan", melainkan terdapat kandungan penggenapan eskatologi dari hukum Taurat. Dan bentuk kata kerja pasif dalam konteks ini, merujuk kepada oknum tersirat, yaitu Yesus Kristus. Dengan demikian, Yesus Kristus yang "menggenapi" seluruh hukum Taurat di dalam pengajaran-Nya dengan menyoroti kasih kepada sesama sebagai penggenapan sejati dan tertinggi dari hukum Taurat. ${ }^{147}$

Moo hanya menekankan aspek pasif dari kata "digenapi" $\left(\pi \epsilon \pi \lambda \eta^{\prime} \rho \omega \tau \alpha \iota\right)$. Sebenarnya kata ini mengandung unsur pasif dan aktif, yang berarti Kristus menggenapi hukum Taurat untuk dan melalui jemaat Galatia. ${ }^{148}$ Dengan demikian selain Yesus Kristus "menggenapi" hukum Taurat bagi jemaat Galatia, jemaat Galatia juga perlu menggenapi hukum Taurat. ${ }^{149}$

145 Ibid., 346.

146 Moo, Galatians, 346. Berkenaan dengan keutuhan hukum Taurat, Moo berpendapat: "Most grammars argue that the unusual attributive pattern emphasizes the "wholeness," contrasting the whole with the parts" (Galatians, 350). Untuk pembahasan secara mendetail, Lih. Additional Notes dari Gal. 5:14 bagian ke-2 (Galatians, 350).

147 Moo, Galatians, 347-48. Hal yang sama juga dibahas oleh Moo dalam pembahasan Rm. 8:4: "This, of course, is exactly what Jesus Christ has done. As our substitute, he satisfied the righteous requirement of the law, living a life of perfect submission to God. In laying upon him the condemnation due all of us ( $\mathrm{Rm}$. 8:3b; cf. Rm. 8:1), God also made it possible for the righteous obedience that Christ had earned to be transferred to us.... And the law's just demand is fulfilled in Christians not through their own acts of obedience but through their incorporation into Christ. He fulfilled the law; and, in him, believers also fulfill the law perfectly, so that they may be pronounced "righteous," free from "condemnation" (Rm. 8:1). It is in this way that Paul's stress on faith "establishes the law" (Rm. 3:31), for, in grasping Christ by faith, people are accounted as really having "done the law." Indeed, as Paul makes clear in this letter, it is only through faith in Christ that the law can really be accomplished." Lih. The Epistle to the Romans, 483-84.

148 Rosner, Paul and the Law, 121-24.

149 Thielman, Paul and the Law, 140; George, Galatians, 379-81; Troels Engberg-Pedersen, "Paul, Virtues, and Vices", dalam Paul in the Greco-Roman World: A Handbook, ed. J. Paul 
Oleh sebab itu, Paulus menegaskan lagi bahwa Kristus sudah menginaugurasi zaman baru, dimana "ketaatan kepada hukum Taurat" mengambil bentuk baru, yaitu bentuk Kristologi. Dengan demikian, jemaat Galatia dapat melayani sesama "di dalam kasih", sebab kasih merupakan arti sejati dan "penggenapan” dari hukum Taurat dalam zaman baru ini. ${ }^{150}$ Dengan petunjuk (kasih) dan kuasa (Roh), maka jemaat Galatia dapat menjalani hidup baru seperti yang diharapkan oleh Paulus. ${ }^{151}$

\section{Galatia 5:16-26}

Paulus menggunakan metafora "jalan" ( $\left.\epsilon \rho \iota \pi \alpha \tau \tau^{\prime} \omega\right)$ yang diresepsi dari kata Ibrani הָרוּ. Dengan demikian Paulus menggambarkan jalan kehidupan yang perlu ditaati. Dan kata ini dalam bentuk present tense, memberi nuansa tindakan yang berkesinambung. Oleh sebab itu, Paulus menasihatkan perlunya terus berjalan menurut pimpinan Roh, baik dalam mengarahkan maupun memampukan kehidupan jemaat Galatia. ${ }^{152}$

Menurut Moo, dengan "berjalan menurut Roh", maka jemaat Galatia akan terhindar dari "memenuhi" ( $\left.\tau \in \lambda \epsilon^{\prime} \omega\right)$ keinginan daging. Sebab dalam zaman baru, Roh yang telah diinagurasikan oleh Kristus, mampu

\footnotetext{
Sampley (Harrisburg: Trinity Press International, 2003), 617.

150 Moo, Galatians, 348. Hal yang sama juga dibahas oleh Moo dalam pembahasan Rm. 13:8: "Christians who love others have satisfied the demands of the law en toto; and they need therefore not worry about any other commandment" Lih. The Epistle to the Romans, 814.

Demikian juga dalam Rm. 13:9: "At issue, then, is whether, in "summing up" the OT commandments about our relations to others, the love command replaces these commandments or whether it simply focuses them by setting forth a demand that is integral to each one of them. When we remember that Paul has earlier in Romans proclaimed the Christian's freedom from the "binding authority" of the Mosaic law (Rm. 6:14, 15; 7:4; 8:4), the former alternative seems to be closer to the truth. The Christian, who belongs to the New Covenant people of God, is no longer "under the [Mosaic] law," the law for the Old Covenant people of God; he is under a "new law," "the law of Christ" (see Gal. 6:2 and 1 Cor. 9:19-21). And central to this new law is a command that Christ himself took from the Mosaic law and made central to his new demand: the command to love our neighbors as ourselves" Lih. The Epistle to the Romans, 816-17.

151 Moo, Galatians, 348.

152 Ibid., 352-53.
} 
menaklukkan segala nafsu dosa. ${ }^{153}$

Namun demikian, menurut Moo, terdapat konflik antara kedua kuasa dalam diri jemaat Galatia yang telah dimerdekakan oleh Kristus. Konflik tersebut antara Roh Allah dan hasrat dari dosa. Sekalipun hasrat tersebut tidak lagi menguasai orang percaya, namun masih memberikan pengaruh yang harus terus dilawan. ${ }^{154}$

Menurut Paulus, keinginan Roh berlawanan dengan keinginan daging, "sehingga kamu setiap kali tidak melakukan apa yang kamu kehendaki." Menurut Moo, ini berarti tidak dapat menjalankan keinginan secara otonomi (baik ataupun jahat). Karena kuasa "daging" dan "Roh" mempengaruhi tindakan seseorang. Sehingga seseorang tidak mempunyai pilihan untuk melakukan apa yang mereka kehendaki, melainkan apa yang dikehendaki oleh daging ataupun oleh Roh. ${ }^{155}$

Untuk menghindari pertentangan yang sebanding antara daging dan Roh, maka Paulus menggunakan frasa "tetapi jikalau" ( $\epsilon$ ' $\delta \grave{\epsilon})$ untuk menyatakan keunggulan Roh. Sebab Roh adalah kemenangan bagi jemaat Galatia. Paulus menggunakan frasa “dipimpin oleh Roh" ( $\pi \nu \in u ́ \mu \alpha \tau \iota$ ״̌ $\gamma \epsilon \sigma \theta \epsilon$, present tense) untuk mengusulkan ide hidup yang terus menerus dipengaruhi dan diarahkan oleh Roh. Dengan hidup yang dipimpin oleh Roh, berarti jemaat Galatia tidak hidup "di bawah hukum Taurat" (úmò vónov). Menurut Moo, hal ini berarti jemaat Galatia tidak lagi harus tunduk di bawah pengaturan hukum Taurat. ${ }^{156}$ Dengan demikian Paulus

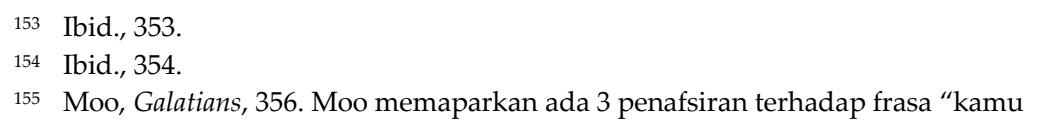

155 Moo, Galatians, 356. Moo memaparkan ada 3 penafsiran terhadap frasa "kamu kehendaki" ( $\left(\theta^{\prime} \lambda \eta \tau \epsilon\right)$ ini: (1) Keinginan untuk melakukan apa yang Roh kehendaki, namun penafsiran ini terbentur dengan konstruksi indefinite dari ' $\mathfrak{c}^{\alpha} \nu \theta^{\prime} \hat{\epsilon} \lambda \eta \tau \in$ dan pernyataan negatif dari ayat 17 menjadi landasan bagi janji positif dari ayat 16, kurang meyakinkan; (2) Keinginan untuk melakukan apa yang daging kehendaki, namun penafsiran ini terbentur juga dengan konstruksi indefinite dari '̇̀̀े $\theta^{\prime} \dot{\lambda} \eta \tau \epsilon$, sehingga rujukan kepada "daging" maupun "Roh" dalam posisi seimbang; (3) Keinginan dalam kontrol manusia secara otonomi (baik atau jahat), namun kesulitan dari penfsiran ini adalah: apakah ketidakmampuan kehendak manusia ini sejalan dengan janji dari ayat 16. Menurut Moo, tafsiran terakhir merupakan tafsiran yang paling minor permasalahannya. Lih. Galatians, 355-56.

156 Moo, Galatians, 357. Menurut Moo, "di bawah hukum Taurat" (i̛mò vó seseorang di bawah yurisdiksi dari hukum Taurat. Lih. Additional Notes dari Gal. 3:23. Lih. 
ingin menegaskan jemaat Galatia sudah dibawah pengaruh dari Roh, sebagai anggota dari perjanjian Allah, di mana hukum Musa sudah tidak lagi memiliki otoritas yang mengikat. ${ }^{157}$

Selanjutnya Paulus membandingkan "perbuatan-perbuatan daging" (Galatia 5:19-21) dan "buah Roh" (Galatia 5:22-23). Menurut Moo, ini merupakan elaborasi dari ayat 17 mengenai "keinginan daging" dan "keinginan Roh". 158

Setelah membahas mengenai "buah Roh", Paulus mengatakan: "tidak ada hukum yang menentang hal-hal itu". Namun hukum apa yang dimaksud? Menurut Moo, ada tiga tafsiran mengenai hal ini: (1) Hukum Taurat; (2) Hukum secara umum, termasuk hukum Taurat; (3) Melampaui tataran hukum. Dengan menunjukkan relevansi hukum Taurat, Moo berpendapat bahwa tafsiran kedua yang sesuai dengan maksud Paulus. Sebab, kasih merupakan penggenapan terhadap hukum Taurat (ayat 14) dan sebagai kunci bagi penafsiran frasa ini. ${ }^{159}$

\section{Galatia 6:1-10}

Paulus meminta jemaat Galatia untuk secara berkesinambungan untuk saling menanggung ( $\beta \alpha \sigma \tau \alpha \dot{\zeta} \epsilon \tau \epsilon$, present tense) beban satu dengan yang lainnya. Dengan melakukan demikian, maka jemaat Galatia sudah "menggenapi" ( $\dot{\alpha} \nu \alpha \pi \lambda \eta \rho \omega \dot{\sigma \epsilon \tau \epsilon)}$ hukum Kristus. Moo di sini memilih varian kata "menggenapi" dengan bentuk future indicative, sehingga lebih merupakan janji penggenapan oleh Kristus. ${ }^{160}$

Calvin sendiri menerima varian aorist imperative 161 , namun

\footnotetext{
Galatians, 246.

157 Moo, Galatians, 357.

158 Ibid., 357-58.

159 Ibid., 367. Untuk pembahasan ketiga tafsiran tersebut, lih. Galatians, 366-67.

160 Moo menyadari terdapat variant dalam kata $\alpha \nu \alpha \pi \lambda \eta \rho o^{\omega} \omega$ ini. Ada manuskrip yang dalam bentuk aorist imperative ( $\alpha \nu \alpha \pi \lambda \eta \rho \omega ́ \sigma \alpha \tau \epsilon)$ dan kebanyakan dalam bentuk future indicative $(\dot{\alpha} \nu \alpha \pi \lambda \eta \rho \omega ́ \sigma \epsilon \epsilon)$. Lih. Additional Notes dari Gal. 6:2. Lih. Moo, Galatians, 376, 383.

161 "For the composition of the Greek word ' $\alpha \alpha \pi \lambda \eta \rho \omega \omega^{\prime} \alpha \tau \tau^{\prime}$ conveys the idea of what is absolutely perfect. But as no man performs in every respect what Paul requires, we are still at a distance from perfection. He who comes the nearest to it with regard to others, is yet far distant with respect to God." Lih. Calvin, Galatians \& Ephesians, 173.
} 
menurut Spence-Jones, perbedaan tersebut tidak perlu diperdebatkan. ${ }^{162}$ Selain itu, kedua variant tetap mempertahankan nuansa aktif dan pasif dari sisi manusia. ${ }^{163}$

Namun apa yang dimaksud dengan hukum Kristus? Moo berpendapat bahwa hukum Kristus berbeda dengan hukum Taurat. Dengan demikian jemaat Galatia, tidak lagi "di bawah hukum Taurat", melainkan di bawah hukum Allah, yang adalah hukum Kristus (1 Korintus 9:20-21), sebab Kristus sudah menggenapi hukum Taurat (Roma 10:4). Walaupun demikian, tambah Moo, hukum Taurat diambil dan diterapkan kembali kepada umat perjanjian baru Allah, khususnya bagian hukum Taurat yang diintegrasikan dalam hukum Kristus. ${ }^{164}$ Namun hukum Taurat bagian mana yang dimaksud, Moo tidak menjelaskan.

Dengan demikian "hukum Kristus" merupakan cara lain bagi Paulus untuk mengatakan teladan dan pengajaran dari Kristus di dalam Injil dan juga pengajaran dari para Rasul Tuhan Yesus. ${ }^{165}$

162 "The sense comes to much the same, whether in the Greek we read the future indicative or the aorist imperative. If the imperative be retained, it yet adds no new element of precept to the foregoing; the clause so read prescribes the fulfilment of Christ's law in the particular form of bearing one another's burdens. If we read the future, the clause affirms that in so doing we shall fulfil his law; which in the other case is implied." Lih. H. D. M. Spence-Jones, Galatians, The Pulpit Commentary (Bellingham: Logos Research System, 2004), 206.

163 "If in Romans 8 Christ fulfills the law for us, in Romans 13 and Galatians 5 Christ fulfils the law through us." Lih. Rosner, Paul and the Law, 124.

164 Moo, Galatians, 377; Douglas J. Moo, "The Law of Moses or the Law of Christ", dalam Continuity and Discontinuity: Perspectives on the Relationship between the Old and New Testaments, ed. John S. Feinberg (Westchester: Crossway, 1988), 217.

Moo memaparkan dua interpretasi umum terhadap "hukum Kristus" ( iòv vó X focussed on, Christ; (2) The law is a law distinct from the law of Moses, either: (a) the love command, singled out by Christ as the center of the law; (b) the ethical teaching of Christ in general; (c) the example of Christ; (d) or some combination of these." Lih. Galatians, 376-77.

Selain itu Moo juga berpendapat: "Since Paul is using "law of Christ" as a kind of rhetorical counterpart to the law of Moses, we should not insist that "law" will have precisely the same form as it does with reference to the law of Moses." (Galatians, 377). Lih. juga Douglas J. Moo, "Jesus and the Authority of the Mosaic Law," Journal for the Study of the New Testament 20 (1980): 3-49; Douglas J. Moo, "The Law of Christ as the Fulfillment of the Law of Moses", 357-72.

165 Moo, Galatians, 37, 378. Moo menyimpulkan demikian: "I think it higly probable that Paul thought of the law of Christ as including within it the teachings of Jesus and the 
Di tempat lain, Paulus juga menyinggung mengenai "hukum iman" (Roma 3:27), yang berarti prinsip ataupun aturan yang berdasarkan iman, sehingga "hukum" disini bukan merujuk kepada hukum Taurat, menurut Moo. ${ }^{166}$ Demikian juga pembahasan Moo mengenai "hukum Roh" (Roma 8:2), bukan mengacu kepada "hukum Taurat", melainkan sebagai bentuk permainan kata dalam perbandingan dengan hukum Taurat. ${ }^{167}$

Di tempat lain, ketika Paulus mengatakan "kamu juga telah mati bagi hukum Taurat oleh tubuh Kristus" (Roma 7:4), Moo menafsirkan demikian,

while this verse implies that the believer is not directly under the authority of the law ... this is not to say that individual commandments from that law may not be re-applied as 'new covenant law'168

Selain itu Moo juga mengatakan dalam pembahasan "The Law of Moses or the Law of Christ":

In that "fulfillment" of the law, however, some of the Mosaic commandments are taken up and reapplied to the New Covenant people of God. Thus, while the Mosaic Law does not stand as an undifferentiated authority for the Christian, some of its individual commandments remain authoritative as integrated into the law of Christ. ${ }^{169}$

Pada dasarnya Moo mengakui "hukum Kristus" adalah pengajaran dan teladan dari Yesus Kristus yang tidak terlepas dari hukum Taurat, namun dalam mencapai kesimpulan tersebut, Moo enggan untuk menunjukkan keterkaitan langsung antara hukum Taurat dengan "hukum Kristus."

apostolic witness, based on his life and teaching, about what it means to reverence God in daily life" Lih. Moo, "The Law of Christ as the Fulfillment of the Law of Moses", 369.

166 Moo, The Epistle to the Romans, 249-50.

167 Moo, The Epistle to the Romans, 474-76.

168 Moo, The Epistle to the Romans, 415.

169 Douglas J. Moo, "The Law of Moses and the Law of Christ" dalam Continuity and

Discontinuity: Perspectives on the Relationship between the Old and New Testaments, ed. John S.

Feinberg (Westchester: Crossway, 1988), 217. 
Paulus juga meminta jemaat Galatia untuk "menguji pekerjaannya sendiri". Menurut Moo, ini berarti bahwa Paulus tidak pernah

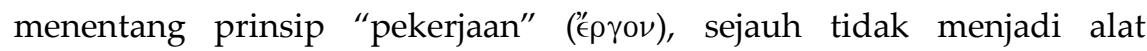
pembenaran di hadapan Allah. ${ }^{170}$ Sebab menurut Paulus, setiap orang "akan memikul" ( $\beta \alpha \sigma \tau \alpha \dot{\sigma} \sigma \mathrm{l}$, future tense) tanggungannya sendiri. Menurut Moo, hal ini tentu mengacu kepada hari penghakiman kelak, dimana setiap orang harus mempertanggungjawabkan perbuatannya di hadapan Allah. ${ }^{171}$

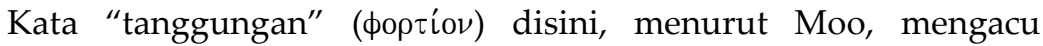
kepada totalitas perbuatan seseorang selama hidupnya yang akan dinilai oleh Allah pada hari penghakiman. ${ }^{172}$

Menurut Moo, setiap individu "bermegah dengan keadaan mereka sendiri" (ayat 4) dan setiap individu bertanggung jawab "memikul tanggungannya sendiri" pada hari penghakiman (ayat 5). Maka dalam pelaksanaannya, Paulus menasihatkan jemaat Galatia untuk "membagi segala sesuatu yang ada padanya dengan orang yang memberikan pengajaran", yaitu: memperhatikan dan menanggung secara finansial mereka yang mengajarkan Injil. ${ }^{173}$

Paulus selanjutnya mengingatkan jemaat Galatia untuk tidak

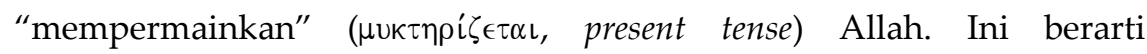
menganggap sepele akan penghakiman yang akan datang. Paulus menjelaskan maksudnya dengan metafora pepatah menabur-menuai untuk menggambarkan hukum sebab-akibat. Menurut Moo, metafora ini dikaitkan dengan pembahasan ayat 8, mengenai ketaatan jemaat Galatia dalam terang penghakiman yang akan datang. ${ }^{174}$

Dalam ayat 8, Paulus membandingkan "menabur dalam daging" dan "menabur dalam Roh". "Menabur", berarti tindakan ataupun

\footnotetext{
170 Moo, Galatians, 379.

171 Ibid., 381. Menurut Moo, dengan menempatkan interpretasi eskatologi demikian, barulah tidak terjadi konflik antara "memikul" (ayat 5) dengan "memikul" (ayat 2)

(Galatians, 381).

172 Ibid., 381.

173 Ibid., 382-83.

174 Ibid., 384.
} 
kelakuan seseorang, sedangkan "menuai", berarti konsekuensi dari tindakan ataupun kelakuan tersebut pada hari penghakiman, menurut Moo. 175 Yang "menabur dalam daging" akan menuai "kebinasaan" $(\phi \theta 0 \rho \alpha)$, hal ini apabila dikaitkan dengan kekekalan, berarti penghakiman kekal. ${ }^{176}$ Yang "menabur dalam Roh" akan menuai "hidup yang kekal”

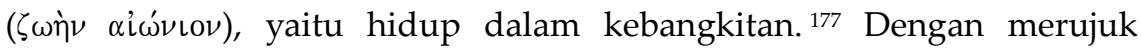
kepada "kebinasaan" dan "hidup yang kekal", menurut Moo, maka Paulus tidak membicarakan mengenai derajat pahala yang akan diperoleh untuk kehidupan berikutnya, melainkan kehidupan itu sendiri, yaitu: keselamatan. ${ }^{178}$

Moo segera menegaskan bahwa pekerjaan manusia yang berkenan kepada Roh diperlukan bagi keselamatan pada akhirnya. Namun pekerjaan ini merupakan efek dari iman dan dihasilkan oleh dan melalui Roh. Dengan demikian, pekerjaan merupakan bukti dari iman. ${ }^{179}$

Melanjutkan metafora menabur-menuai, Paulus mengingatkan jemaat Galatia untuk "tidak jemu-jemu berbuat baik", sebagai bentuk "menabur dalam Roh". Sebab dengan demikian, maka jemaat Galatia

\footnotetext{
175 Ibid., 386.

176 Ibid., 386; Lih. juga Douglas J. Moo, "Israel and the Law in Romans 5-11: Interaction with the New Perspective" dalam The Paradoxes of Paul, 185-216.

177 Moo, Galatians, 386.

178 Moo, Galatians, 386-87. Moo juga menekankan bahwa kehidupan berikutnya memiliki unsur kontinuitas dan dikontinuitas dengan kehidupan sekarang: "Paul does not see "new creation" as a simple replacement of this creation. The transition from this creation to the next will be discontinuous to some extent, but Paul's language of "liberation" and "reconciliation" requires a basic continuity as well. The creation in which we now live is, in some important way, continuous with the creation that is to come. The cosmic aspect of new creation is not a "creation out of nothing" (creatio ex nihilo) but a "creation out of the old" (creatio ex vetere)." Lih. Douglas J. Moo, "Creation and New Creation," Buletin for Biblical Research 20.1 (2010): 60.

179 Moo, Galatians, 387. Berkaitan dengan ketegangan "penghakiman berdasarkan perbuatan" dan "pembenaran melalui iman", Moo berpendapat: "Evangelicals in the broadly Reformed tradition have usually responded to this problem by arguing (1) that our works will have a bearing on the "reward" that we receive but not on salvation per se and/or (2) that works are the product or "evidence" of faith. I don't think the former is exegetically responsible. The latter has much more to be said for it and certainly captures an important aspect of biblical teaching. It is therefore usual to speak of works as the evidence of faith. And this way of approaching the matter has some grounding in Galatians." Lih. Moo, "Justification in Galatians", 194.
} 
"akan menuai, jika tidak menjadi lemah". Namun mengapa Paulus memberi indikasi negatif tersebut? Menurut Moo, sebab seiring waktu kelesuan bisa terjadi, sama halnya yang disampaikan oleh Paulus dalam 2 Tesalonika 3:13. Dengan demikian, maka Paulus menggunakan frasa

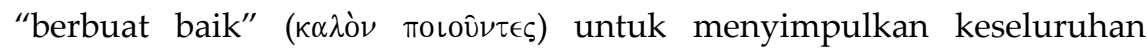
tanggung jawab orang percaya. ${ }^{180}$

Dengan nasihat untuk "berbuat baik" dalam ayat 10, menurut Moo, sebagai rangkuman dari keseluruhan Galatia 6:1-10. Panggilan "berbuat baik" ini ditujukan kepada "semua" ( $\pi \alpha \dot{\alpha} \nu \tau \alpha \varsigma)$ orang tanpa batasan, termasuk orang percaya maupun tidak. Terlebih lagi kepada "keluarga

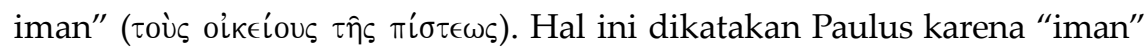
menjadi ciri dari keluarga spiritual yang baru. "Iman dalam Kristus" inilah yang menjadi dasar dan tanda pembaharuan bagi umat perjanjian baru Allah. ${ }^{181}$

Dalam perikop ini, Moo tidak secara spesifik mengatakan bahwa norma untuk "berbuat baik" apakah berasal dari hukum Taurat, namun merupakan akibat dari hidup yang dipimpin oleh Roh.

\section{Kesimpulan}

Setelah pembahasan secara sinkronis dalam surat Galatia, mulai dari bagian indikatif hingga bagian imperatif; mulai dari pemaparan Paulus mengenai pentingnya iman dalam Kristus (dan bukan ketaatan kepada hukum Taurat), hingga pentingnya mengenapi hukum Taurat bagi jemaat Galatia. Dapat disimpulkan Moo mempertahankan kontinuitas hukum Taurat dalam tafsiran surat Galatia.

Moo masih mempertahankan pemahaman tradisi Reformed ${ }^{182}$, dimana menekankan aspek antropologis, yudisial serta kanonikal dari hukum Taurat. Aspek antropologis dimana manusia berada di bawah

\footnotetext{
180 Ibid., 387-88.

181 Ibid., 389.

182 "Following the lead of Calvin and many others in the Reformed tradition, we think it does much better justice to Paul ... ", Moo Galatians, 56, lihat juga 232.
} 
ikatan dosa, sehingga manusia tidak mungkin dapat menaati hukum Taurat sepenuhnya. Aspek yudisial menunjukkan bagaimana manusia dibenarkan serta statusnya di hadapan Allah. Aspek kanonikal, Moo menempatkan surat Galatia sebelum konsili di Yerusalem (Kisah Para Rasul 15:1-29) untuk (1) menegakkan legitimasi catatan dari Lukas; dan (2) menghindari kesan ketidak-konsistenan dalam pribadi Petrus.

Akan tetapi Moo, akibat pengaruh Lutheran 183, sangat memisahkan hukum Taurat dan Injil, 184 sehingga ketika membahas "penggenapan" hukum Taurat dalam Galatia 5:14 dan Galatia 6:2, sepertinya tidak secara langsung mengaitkan penggenapan ini dengan

183 Moo secara eksplisit memposisikan diri mewakili "A Modified Lutheran View" dalam buku Greg L. Bahnsen, Five Views on Law and Gospel, Counterpoints (Grand Rapids: Zondervan, 1996), 319-76.

184 Pengamatan ini juga diungkapkan oleh Green: “A radical law-gospel antithesis is commonly attributed to Martin Luther and Lutheran orthodoxy. It is also suggested that traditional Reformed theology or Reformed orthodoxy has a more modified understanding of the purported law-gospel contrast or antithesis" Lih. Bradley G. Green, Covenant and Commandment: Works, Obedience, and Faithfulness in the Christian Life, New Studies in Biblical Theology, vol. 33 (Downers Grove: IVP, 2014), 60. Lih. juga pembahasan Rosner, Paul and the Law, 21.

Luther dalam pembahasan Gal. 2:14 membuat pemisahan yang kentara antara hukum dan Injil: "Therefore whoever knows well how to distinguish the Gospel from the Law should give thanks to God and know that he is a real theologian. I admit that in the time of temptation I myself do not know how to do this as I should. The way to distinguish the one from the other is to locate the Gospel in heaven and the Law on earth, to call the righteousness of the Gospel heavenly and divine and the righteousness of the Law earthly and human, and to distinguish as sharply between the righteousness of the Gospel and that of the Law as God distinguishes between heaven and earth or between light and darkness or between day and night. Let the one be like the light and the day, and the other like the darkness and the night. If we could only put an even greater distance between them! Therefore if the issue is faith, heavenly righteousness, or conscience, let us leave the Law out of consideration altogether and let it remain on the earth. But if the issue is works, then let us light the lamp of works and of the righteousness of the Law in the night. So let the sun and the immense light of the Gospel and of grace shine in the day, and let the lamp of the Law shine in the night". Lih. Martin Luther, Luther's Works, Vol. 26: Lectures on Galatians, 1535, Chapters 1-4, ed. Jaroslav Jan Pelikan, Hilton C. Osward dan Helmut T. Lehmann (Saint Louis: Concordia, 1963), 26:115-16.

Perbedaan ini disebabkan karena 2 aliran penafsiran terhadap pemikiran Paulus: (1) sejarah keselamatan (heilsgeschichtlich); (2) apokaliptik. Lih. Meyer, The End of the Law, 3. Carson menggunakan 2 istilah yang berbeda: (1) promise and fulfillment; (2) hiddenness and revelation. Lih. Carson, "Mystery and Fulfillment", 397. Lih. juga James D. G. Dunn, "How New Was Paul's Gospel? The Problem of Continuity and Discontinuity", dalam Gospel in Paul: Studies on Corinthians, Galatians, and Romans for Richard N. Longenecker, ed. L. A. Jervis dan P. Richardson (Sheffield: Sheffield, 1994), 367-88. 
ketaatan kepada hukum Taurat. Hal ini berbeda dengan pandangan Calvinist yang lebih akomodatif terhadap hukum Taurat. ${ }^{185}$ Dengan demikian, Moo gagal untuk menghargai dimensi anugerah dari hukum Taurat sebagai bagian dari perjanjian Allah, ${ }^{186}$ dan gagal untuk melihat fungsi hukum Taurat secara positif. ${ }^{187}$

Moo dalam tulisannya menegaskan bahwa hukum Taurat sudah digenapi oleh Kristus, sehingga jemaat Galatia di dalam iman kepada Kristus dipanggil untuk memenuhi hukum Kristus dengan pertolongan

185 Misalnya: Richard G. Gaffin dan Geerhardus Vos. Gaffin berpendapat demikian:

"From this perspective, the antithesis between law and gospel is not an end in itself. It is not a theological ultimate. Rather, that antithesis enters not by virtue of creation but as the consequence of sin, and the gospel functions for its overcoming. The gospel is to the end of removing an absolute law-gospel antithesis in the life of the believer. How so? Briefly, apart from the gospel and outside of Christ the law is my enemy and condemns me. Why?

Because God is my enemy and condemns me. But with the gospel and in Christ, united to him by faith, the law is no longer my enemy but my friend. Why? Because now God is no longer my enemy but my friend, and the law, his will, the law in its moral core, as reflective of his character and of concerns eternally inherent in his own person and so of what pleases him, is now my friendly guide for life in fellowship with God. Lih. Richard B. Gaffin, By Faith, Not by Sight: Paul and the Order of Salvation (Bletchley: Paternoster, 2006), 103.

Demikian juga pendapat yang sama oleh Vos: "It is plain, then, that law-keeping did not figure at that juncture as the meritorious ground of life-inheritance. The latter is based on grace alone, no less emphatically than Paul himself places salvation on that ground. But, while this is so, it might still be objected, that law-observance, if not the ground for receiving, is yet made the ground for retention of the privileges inherited. Here it cannot, of course, be denied that a real connection exists. But the Judaizers went wrong in inferring that the connection must be meritorious, that, if Israel keeps the cherished gifts of Jehovah through the observance of His law, this must be so, because in strict justice they had earned them. The connection is of a totally different kind. It belongs not to the legal sphere of merit, but to the symbolico-typical sphere of appropriateness of expression." Lih. Geerhardus Vos, Biblical Theology, Old and New Testament (Grand Rapids: Eerdmans, 1954), 127. Lih. juga Thielman, Paul and the Law, 22.

186 VanGemeren mewakili pemikiran Calvinist mengkritik Moo yang sudah mengabaikan dimensi anugerah dari hukum Taurat: "Is it any wonder that Moo fails to appreciate the place of God's word to Moses in the new covenant? Certainly, the law was part and parcel of the old covenant structure. It tended to obscure the gracious dimension of the covenant relationship by all the negative aspects enumerated by Moo (supervision, imprisonment, revelation of sin, etc.). The prophets, however, did not speak of the new covenant era as a release from the law, but as a spiritual change within the people. The law was to be internalized by God's gracious work within the people. By the work of the Holy Spirit, they would discern the 'spirit' of the law from the harshness of the law." Lih. Bahnsen, Five Views on Law and Gospel, 381.

${ }_{187}$ Berbeda dengan Luther, Calvin memaparkan "the third use of the law" (tertius usus legis) terdapat 2 fungsi positif: (1) untuk mengetahui kehendak Allah; (2) supaya tidak terjerumus di dalam pelanggaran. Lih. Calvin, Institutes, II.vii.12. 
Roh Kudus. Dengan demikian, hukum Taurat tidak memiliki otoritas langsung, tetapi tetap menjadi sumber secara tidak langsung-melalui otoritas pengajaran Perjanjian Baru - untuk kehidupan orang Kristen. 